\title{
THE U.S. GEOLOGICAL SURVEY FEDERAL-STATE COOPERATIVE WATER-RESOURCES PROGRAM FISCAL YEAR 1988
}




\section{THE U.S. GEOLOGICAL SURVEY FEDERAL-STATE COOPERATIVE WATER-RESOURCES PROGRAM FISCAL YEAR 1988}

by B.K. Gilbert and W.B. Mann IV 


\title{
DEPARTMENT OF THE INTERIOR \\ MANUEL LUJAN, JR., Secretary
}

\author{
U.S. GEOLOGICAL SURVEY \\ Dallas L. Peck, Director
}

Copies of this report can be purchased from:

Books and Open-File Reports Section U.S. Geological Survey, Building 810 Federal Center, Box 25425

Denver, CO 80225
For additional information write to:

Assistant Chief Hydrologist for Operations U.S. Geological Survey Water Resources Division 441 National Center 12201 Sunrise Valley Drive Reston, Virginia 22092 
CONTENTS

$\underline{\text { Page }}$

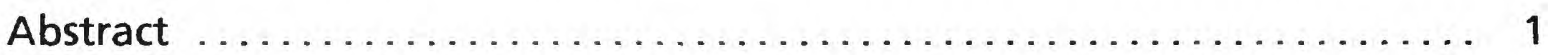

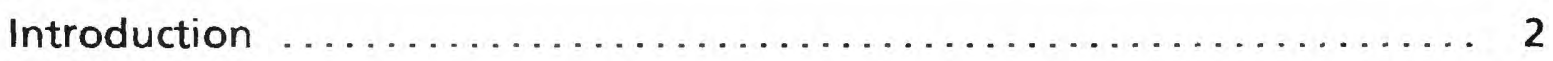

Functions of the Cooperative

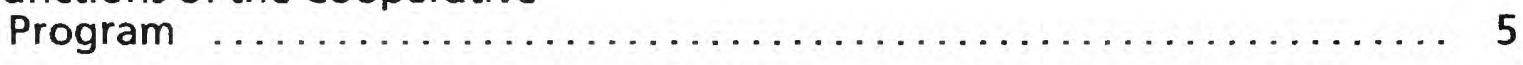

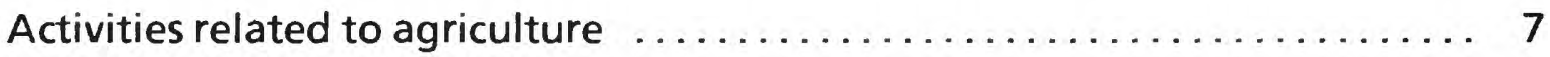

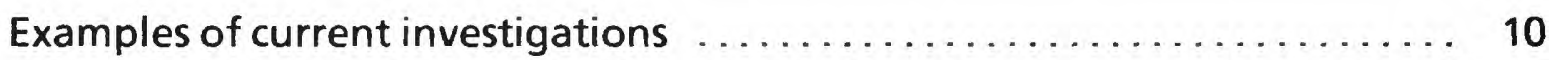

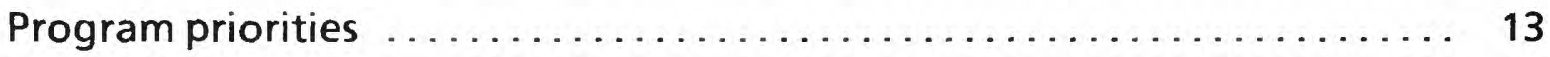

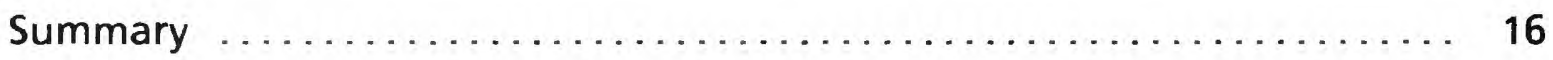

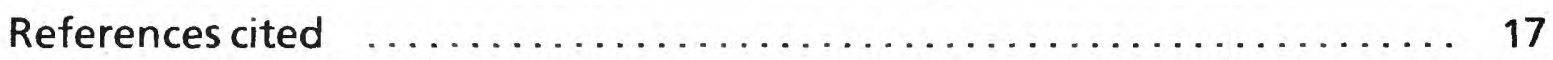

Appendix A: List of cooperators by State, fiscal year $1988 \ldots \ldots \ldots \ldots \ldots 18$

Appendix B: List of selected U.S. Geological Survey investigations and

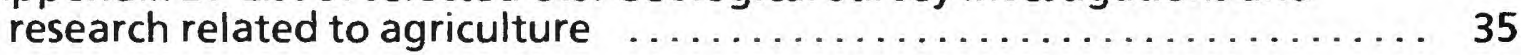

Figures

Figure 1: Graph showing actual obligations of the U.S. Geological Survey's Water Resources Division, fiscal year 1988

Figure 2: Graph showing the number of U.S. Geological Survey investigations related to agricultural activities that were ongoing each year, 1970 through 1988 

The U.S. Geological Survey Federal-State

Cooperative Water-Resources Program,

Fiscal Year 1988

by Bruce K. Gilbert and William B. Mann IV

\section{ABSTRACT}

The Federal-State Cooperative Program is a partnership between the U.S. Geological Survey and State and local agencies. It provides a balanced approach to the study and resolution of water-related problems and to acquiring hydrologic data. The principal program objectives are to: (1) collect, on a systematic basis, data needed for the continuing determination and evaluation of the quantity, quality, and use of the Nation's water resources, and (2) appraise the availability and the physical, chemical, and biological characteristics of surface and ground water through analytical and interpretive investigations. During fiscal year 1988, hydrologic data collection, interpretive investigations, and research were conducted by Geological Survey personnel in offices in every State, Puerto Rico, and several territories in cooperation with more than 1,000 local, State, and regional agencies. In fiscal year 1988 , Federal funding of almost $\$ 60$ million was matched by cooperating agencies, who also provided approximately $\$ 6$ million unmatched for a total program of about $\$ 126$ million. This amounted to more than 40 percent of the total funds for Geological Survey water-resources activities.

This report presents examples of current (1988) investigations. It also lists about 250 water-resources investigations related to agricultural activities that the Geological Survey conducted from 1970 to 1988. 
The complexities involved in the appraisal of the Nation's water resources precludes the accomplishment of this task by Federal efforts alone. Similarly, State and local agencies working independently do not always relate to the larger regional aspects of the hydrologic system. Cooperative planning of data collection and investigations permits a balanced Federal-State-local approach to the study and resolution of water-related problems.

The Federal-State Cooperative Program, a partnership between the U.S. Geological Survey and State and local agencies, provides such a balance for water-resources investigations. The principal program objectives are to: (1) collect, on a systematic basis, data needed for the continuing determination and evaluation of the quantity, quality, and use of water resources in the United States, and (2) appraise the availability and the physical, chemical, and biological characteristics of surface and ground water through analytical and interpretive investigations. The resulting information forms the foundation for many of the Nation's waterresources management and planning activities. In addition, the information may function as an early warning of emerging water problems.

The Cooperative program has contributed directly to water-resources knowledge for more than 90 years by fostering a working partnership between the Federal and State governments in the advancement of earth science, and by compiling a major part of the Nation's hydrologic information. From its earliest days, the program has been directly responsible for the development of streamgaging procedures, surfacewater and ground-water flow concepts, and water-quality analytical techniques and investigations.

The first Geological Survey cooperative water-resource investigation was with the State of Kansas in 1895. In 1905, Congress appropriated funds specifically for cooperative studies, marking the official beginning of the program. In 1928 , Congress gave formal recognition to the Federal-State partnership and limited the Federal financial contribution for cooperative water-resources studies to no more than 50 percent of the funds for each investigation.

During Fiscal Year (FY) 1988, hydrologic data collection, interpretive investigations, and research were conducted by Geological Survey personnel in offices in every State, Puerto Rico, and several territories in cooperation with more than 1,000 local, State, and regional agencies (see appendix A). State, county, and municipal agencies participate in the program, as do interstate compact organizations, conservation districts, sanitary districts, drainage districts, flood-control districts, and other similar organizations. In FY 1988, Federal funding of almost $\$ 60$ million was matched by the cooperating agencies; cooperators also furnished approximately $\$ 6$ million unmatched, for a total of about $\$ 126$ million. This was more than 40 percent of the total funds for the Geological Survey's program of water-resources activities (figure 1). The Federal-State Cooperative Program is unique in that local and State agencies provide at least one-half the funds, but the Geological Survey does most of the work. At times, the cooperator's contribution to the program may be partly in the form of direct expenditures. This refers to mutually agreed upon work for which dollarvalue credit is given by Geological Survey for services rendered by the cooperator in support of program objectives. 


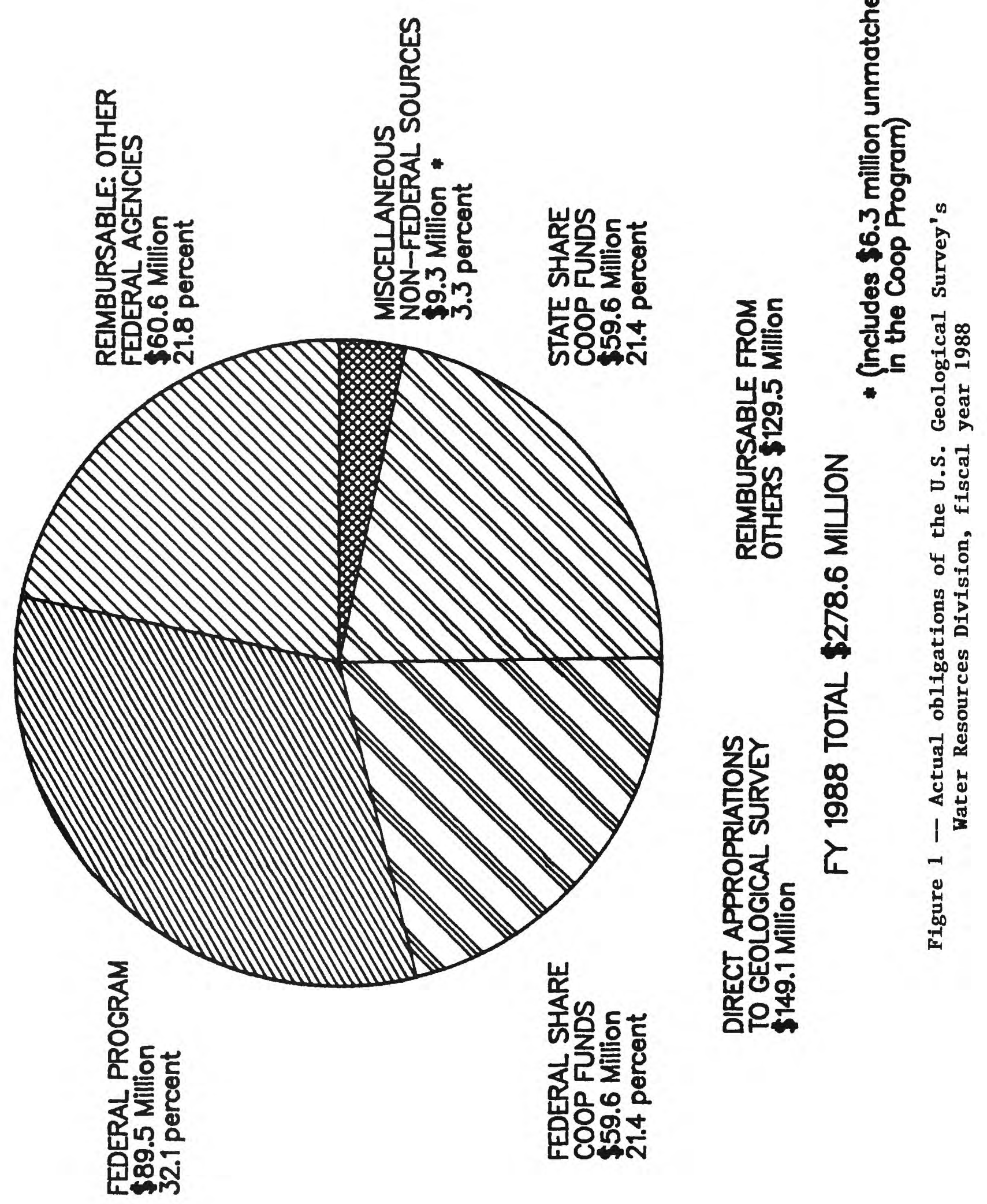


Information provided from the Cooperative Program has relevance to potential and emerging long-term problems, such as water supply, waste disposal, energy production, and environmental protection. Because common methods and techniques are used, the information also is relevant to problems having interstate, regional, national, or international significance. The benefits of the program are demonstrated, in part, by the extent to which other agencies use the information produced. For example, the National Weather Service uses streamflow and waterlevel information from about 3,000 Geological Survey-operated streamgaging stations for their flow- and flood-forecasting systems. More than 40 percent of the funds for the support of these stations is derived from the Geological Survey

Cooperative Program. 


\section{FUNCTIONS OF THE COOPERATIVE PROGRAM}

In fulfilling its water-resources mission, the Geological Survey performs four principal functions:

- Data collection needed for the continuing determination and evaluation of the quantity, quality, and use of the Nation's water resources.

- Analytical and interpretive appraisals to describe the occurrence, availability, and physical, chemical, and biological characteristics of surface and ground water.

- Research in hydraulics, hydrology, and related scientific and engineering fields.

- Dissemination of water data and the results of investigations and research.

The collection of surface-water and ground-water data on a systematic basis under the provisions of the Federal-State Cooperative Program is a major part of the Geological Survey's coordinated water-resources activities. The resulting information provides a continuing record of the quantity and quality of the Nation's water resources. In FY 1988, the Federal-State Cooperative Program funded totally the operation of 3,800 continuous streamflow stations and funded, in combination with other sources, another 1,300 continuous streamflow stations. These stations constitute more than half the continuous streamflow stations operated by the Geological Survey.

The program provided funds for the collection of ground-water levels at almost 30,000 sites. The FY 1988 program also provided for collection of water-quality data at a total of 2,000 surface-water stations and a total of 6,300 ground-water stations. Overall in FY 1988, the Cooperative Program accounted for 88 percent of the Geological Survey's activities in ground-water data collection.

During FY 1988, the Geological Survey also conducted about 900 interpretive and research investigations, of which about 500 were part of the Cooperative Program. Interpretive investigations encompass areas that range in size from a square mile or less to multistate regions. In these investigations Geological Survey scientists bring together information to define, characterize, and evaluate the areal extent, quality, and availability of the water resource. Since the early 1970's, these investigations have emphasized water-quality issues, such as aquifer contamination, acid rain, river-quality assessments, and storm runoff.

Deterioration in the quality of water supplies for domestic, municipal, industrial, and agricultural uses is a growing problem, which can affect human health as well as the economy. At least half of the Nation's population uses ground water for drinking water. In some places, especially in densely populated and industrialized areas, disposal of toxic wastes has made ground water unsafe for use. For an isolated point source of contamination, such as an industrial disposal pond, the consequences may be severe in magnitude, but only local in extent. In some places, however, many separate agricultural and industrial activities located over a large area are contributing to widespread contamination. The intensive and multiple uses of the Nation's rivers also have contributed to water-quality problems. Historically the rivers have been used for water supplies, dilution of waste, recreation, commerce, and for production of fish and other aquatic crops. These uses are not all 
compatible, and over time many problems, which managers are attempting to solve, have surfaced.

The Nation's ability to cope with new and challenging problems in ground-water development and management rests in large measure on information from investigations conducted during the past years in the Cooperative Program.

All data and results of analytical studies are made available to cooperating agencies and the public through various published reports (about 1,500 in FY 1988), and through computerized information programs such as the National Water Data Storage and Retrieval System (WATSTORE) and the National Water Data Exchange (NAWDEX) Program. Abstracts of completed reports are made available through the Geological Survey Water Resources Scientific Information Center (WRSIC).

Included as part of the Federal-State cooperative activities are the:

- Water-Use Information Program, which is designed to determine how much water is withdrawn for use; how much water is consumed during use; the purpose for which water is used; where and how much water is returned; the effect of use on water quality; and the factors that influence water use. As of FY 1988, all States except Rhode Island are participating in this program.

- Coal Hydrology Program, which is designed to assess hydrologic conditions and water-supply problems related to coal mining and land reclamation as these needs are identified jointly by the Geological Survey and by State and local governments. These studies will expedite the preparation of applications for mining permits and mine plans by the coal industry by providing needed hydrologic data. The information will also aid State authorities in reviewing the applications and plans. 
Because agriculture is so universally dependent on the availability, distribution, and quality of water, many hydrologic data-collection efforts and investigations conducted by the Geological Survey have importance to agricultural interests. The Geological Survey was established in 1879, and in 1888 an Act provided specific authorization for surveys to identify irrigable lands in arid regions and for the selection of sites for reservoirs necessary for the storage and utilization of water for irrigation. Thus, almost since the Geological Survey was founded, activities related to agriculture have been included in its programs.

It is noteworthy that the first three reports in the Geological Survey Water-Supply Paper series (originally known as "Water-Supply and Irrigation Papers") are entitled "Pumping water for irrigation" (Wilson, 1896), "Irrigation near Phoenix, Arizona" (Davis, 1897) and "Sewage irrigation" (Rafter, 1897). Furthermore, at least 12 of the first 20 Water-Supply Papers reported on irrigation investigations and other agriculture-related matters. The focus of investigations soon expanded from evaluations of the quantity and quality of ground and surface water available for agriculture to investigations of the effects of agricultural practices on erosion and sedimentation, ground-water levels, and on water quality.

Madison and Brunett (1985, p.98) report that from 1950 to 1970 , fertilizer use in the United States increased from 20 million to 40 million tons per year. Their search of scientific publications indicated that in almost every State investigations were in progress of ground-water contamination by nitrate from agricultural activities. insecticide use on crops is declining gradually on a national basis, but herbicide use is increasing. (Gilliom, 1985, p. 86). The greatest use of pesticides is for agricultural purposes, but the regional-use patterns and the more than 50,000 pesticide products (Gianessi, 1987) make detection in ground and surface water a constantly challenging problem.

In 1985, more than 57 million acres of land in this country were being irrigated (Solley, Merk, and Pierce, 1988). These authors also report that water withdrawals in the United States during 1985 are estimated to have averaged $399,000 \mathrm{Mgal} / \mathrm{d}$ (million gallons per day). Of this amount, about $137,000 \mathrm{Mgal} / \mathrm{d}$ were withdrawn for irrigation. Total consumptive use was estimated to be $92,300 \mathrm{Mgal} / \mathrm{d}$, of which irrigation accounted for $73,800 \mathrm{Mgal} / \mathrm{d}$. It is evident, therefore, that the relations among agriculture, water resources, and the environment are of the utmost importance to the Nation's well-being.

From 1970 through 1988, the Geological Survey had underway more than 250 investigations directly related to agriculture, which are listed in appendix $B$. Of these, 180 (about 70 percent) were conducted as part of the Federal-State Cooperative Program. The Geological Survey Federal Program and the Other Federal Agency Program provided support for the remainder. The average cost per investigation in the Cooperative Program was about $\$ 180,000$; in the Federal Program, about $\$ 470,000$; and in the Other Federal Agency Program, about $\$ 260,000$. The total funding for the 250 investigations amounted to almost $\$ 63$ million, for an overall average of about $\$ 250,000$ per investigation.

Figure 2 shows the number of investigations related to agricultural activities that were ongoing each year from 1970 through 1988. The number increased from 5 in 1970 to a maximum of 101 in 1987, with 94 underway in 1988 . The number of 


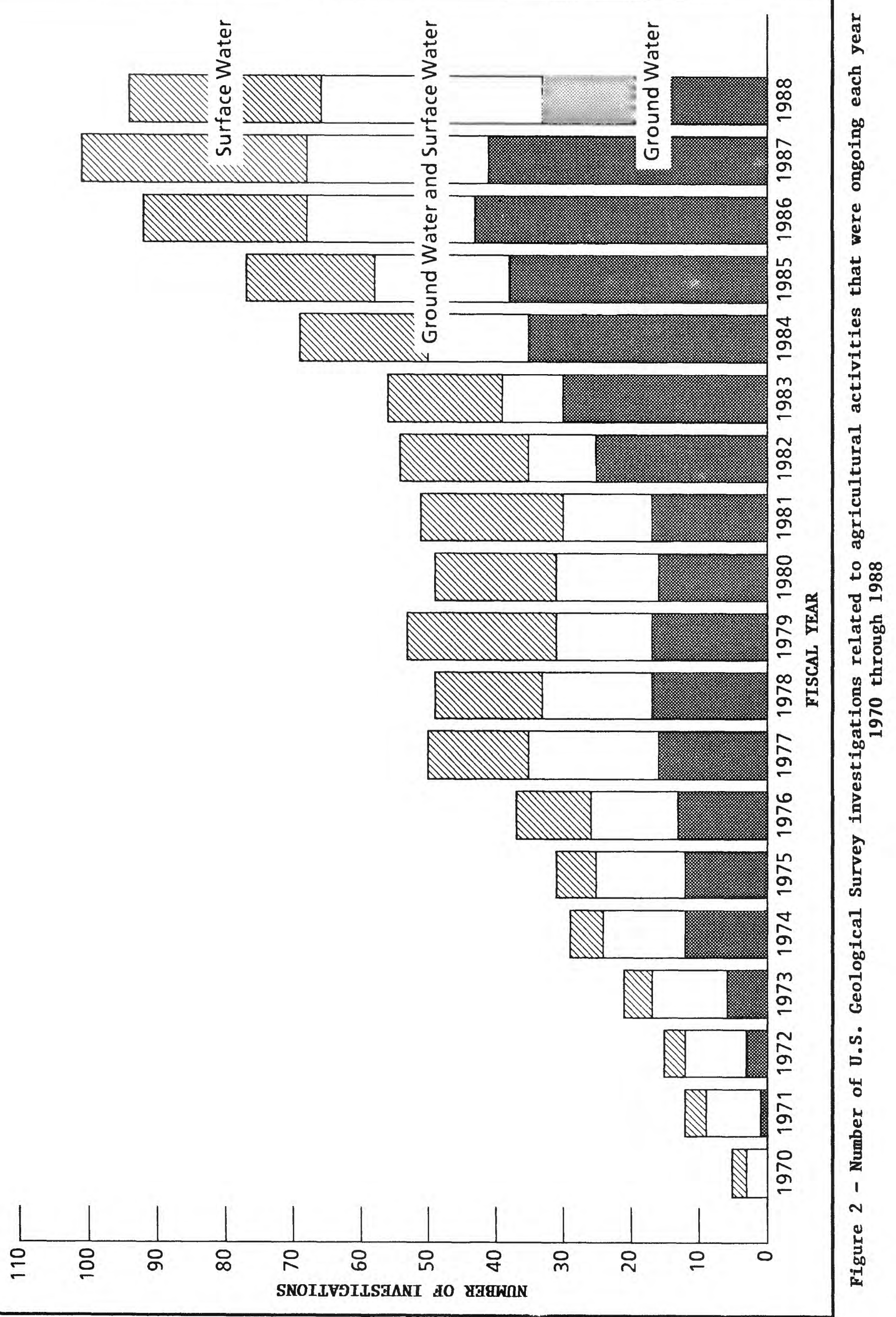


investigations with ground-water components increased from 40 in 1983 to 50 in 1984 , and averaged nearly 70 from 1986 through 1988. These increases reflect the widespread, growing concern regarding ground-water quality. Almost 60 percent of the 94 investigations in FY 1988 were conducted as part of the Cooperative Program.

Examples of selected Cooperative Program investigations related to agricultural activities are included among those shown in the following section of this report. Other examples of investigations related to the effects of agricultural chemicals or practices on water resources in the Cooperative Program and in other Geological Survey programs are described in "Some Aspects of U.S. Geological Survey Activities Related to the Effects of Contaminants on Water Resources" (Gilbert, Mann, and Emery, 1987). 


\section{EXAMPLES OF CURRENT INVESTIGATIONS}

Several examples of recent cooperative investigations follow:

- Pesticides in soil and ground water, lowa River basin, lowa -- Recently established ground-water quality monitoring programs have detected pesticides in a number of shallow ground-water supplies throughout lowa. Increasing concern about the leaching of agricultural chemicals into aquifers has highlighted the need to improve our understanding of the movement of these contaminants. Data collected by the State indicate that nearly 56 million pounds of herbicides are applied annually to fields in lowa. In cooperation with the University of lowa Hygienic Laboratory, the Geological Survey is evaluating the movement and distribution of selected pesticides in the field environment.

- Effects of agricultural best management practices.

-- Patuxent River basin, Maryland: Nutrients in runoff from agricultural areas in the Patuxent River basin substantially affect the water quality of the Chesapeake Bay. Best management practices, proposed to reduce the nutrients in runoff, may increase infiltration to the ground-water flow system and, consequently, increase the concentration of nutrients in shallow ground water. In cooperation with the Maryland Department of Health and Mental Hygiene, the Geological Survey is conducting an investigation to determine the effects of best management practices on ground-water flow and nitrogen concentrations.

--- Lower Susquehanna River basin, Pennsylvania: The Pennsylvania Departments of Environmental Resources and Agriculture are testing traditional programs and best management practices for control of nonpoint-source runoff from agricultural land in the lower Susquehanna River basin. The Geological Survey, in cooperation with the Susquehanna River Basin Commission, has underway an investigation to evaluate the effects of various farming practices on nutrient and sediment discharges in the areas, as well as the effects on the quality of water in the underlying noncarbonate rocks. The study will include an analysis of the relative influence on water quality of physiography, geology, soils, land use, and precipitation as they relate to best management practices.

- Agricultural chemicals in ground water and streams, Missouri -- The initial effort to document the occurrence of pesticides and nitrate in the water resources of intensively developed agricultural areas of Missouri took place in 1986 and 1987. The Geological Survey, in cooperation with the Missouri Department of Health, sampled ground water and streams at 129 sites in the southeast lowlands area. Twenty-three different pesticides were detected, and at least one pesticide was present at most sites. Nitrate concentrations exceeded drinking water standards in 10 of 40 samples from domestic water supplies. As a continuation of this effort, in 1988 samples were being collected and analyzed for pesticides and nitrate from approximately 60 domestic wells in the Missouri River alluvium, northwestern Missouri. 
- Effects of land use on streams in North Carolina -- The North Carolina Department of Natural Resources and Community Development and the Geological Survey are cooperating on the examination of the relations among land use, water quality, and aquatic biota. The study is focusing on concentrations of suspended sediment, heavy metals, and nutrients in three streams in the North Carolina Piedmont. One of the streams drains a predominantly forested area, one drains an agricultural area, and one drains an urban area. The biological health of each stream is being measured by monitoring the macroinvertebrate communities. Data show that all three land-use types contribute high concentrations of suspended sediment to the receiving streams, but highest concentrations are found in the urban stream. In general, metals are highest in the urban stream, but nutrients are substantially higher in the agricultural stream.

- Solute transport in the unsaturated zone, Tucson basin, Arizona -- In cooperation with the city of Tucson, the Geological Survey is investigating the mechanisms that control solute transport through the unsaturated zone of the unconsolidated, poorly-sorted alluvial sediments beneath the Santa Cruz River flood plain near Tucson. The knowledge gained is expected to have application in determining how contaminants move through the unsaturated zone in alluvial basins throughout the arid Southwest.

- Pesticides at North Hollywood dump, Memphis, Tennessee -- The Geological Survey, in cooperation with the city of Memphis, is conducting an investigation of hazardous wastes at a closed municipal-industrial landfill, the North Hollywood dump. The site is Tennessee's top-ranking facility on the 'Superfund' list of the U.S. Environmental Protection Agency. The city of Memphis is concerned primarily with the possible contamination of the underlying aquifer, which provides drinking water for almost one million people.

- Ground-water/surface-water relations, Massachusetts -- The flow in many small streams in the Northeast has been reduced to abnormally low levels by pumping from nearby wells. Also, some municipal water-supply wells have been closed because of infiltration of stream water of degraded quality. The Geological Survey, in cooperation with the Massachusetts Division of Water Pollution Control, is using recently developed methods to relate the physical and chemical properties of the stream water, streambed, and underlying aquifer to the quantity and quality of water withdrawn by wells.

- Bridge scour in Delaware, Maryland, and Virginia -- The undermining (scouring) of bridge-pier and abutment foundations by erosive action of water can result in structural failure of bridges. The numerous equations developed to predict scour produce a wide range of estimates for the same set of conditions, and field data to test the validity of these equations are sparse. The Geological Survey, in cooperation with State Highway Departments in Delaware, Maryland, and Virginia, has begun a pilot study to develop techniques for measuring scour continuously at bridge piers to improve the predictive equations.

- Selenium in ground water, Powder River basin, Wyoming -- In cooperation with the Wyoming Department of Environmental Quality, the Geological Survey is conducting an investigation of geochemical processes controlling the concentration of selenium in ground water from coal-mine spoils. 
Results from the study will be used by State regulatory agencies to evaluate aquifer-reclamation strategies at surface coal mines where large concentrations of selenium are present in the overburden. Knowledge gained here is expected to have application to other areas where selenium in ground water is a problem.

- Flood capacity of the Puyallup River basin, Washington -- In cooperation with the Washington Department of Ecology, the Geological Survey is investigating: (1) present and past flow-carrying capacities and streambed elevations of the river channels (most of which are leveed) in the lower Puyallup River basin; (2) sediment processes in the rivers; (3) salmon and steelhead habitat in the streams; and (4) the interrelations among proposed changes in river channels for flood control and the previous three conditions. This infor-mation is of keen interest to government agencies concerned with the need to improve or maintain the present flood capacity of the river channel, and to Indian tribes concerned with fish habitats.

- Nutrients in wetlands streams, Florida -- A study by the Geological Survey in cooperation with the Reedy Creek Improvement District is intended to improve the understanding of the processes governing nutrient cycling and dissolved-oxygen concentrations in a central Florida wetland stream. The objectives are to determine waste-water treatment requirements and to assess the effects of nutrient-enriched effluents on stream quality.

- Monitoring of the Ogallala aquifer--In FY 1988, the USGS began a cooperative effort for increased ground-water level monitoring activities associated with the Ogallala aquifer. As part of the High Plains Aquifer Monitoring Program, deficiencies are being eliminated in the present programs for collection of data on aquifer conditions. The work varies from State to State, but includes the drilling of additional monitoring wells and the measuring of additional water levels; the installation of continuous recorders where the annual fluctuations in water levels are not defined; and the compilation of existing data into compatible formats. 


\section{PROGRAM PRIORITIES}

Program priorities are based on national needs that have been identified by the President and Administration advisors, by the Congress, by the Department of the Interior, by other Federal agencies, and from information the Geological Survey has received from cooperating agencies and other interested parties. Issues that are identified through the National Water Summary (U.S. Geological Survey 1984, 1985, 1986 , and 1988) are also taken into consideration. As a result, the priorities are developed in response to mutual Federal, regional, State, and local requirements.

Thus, the Geological Survey and its cooperating agencies work together in a continuing process that leads to adjustments in each year's program. The number of requests for scientific and technical assistance continues to grow from State agencies responsible for ground-water protection and for controlling and mitigating contamination. The State offerings, which typically exceed Federal matching funds by $\$ 5-\$ 10$ million each year, reflect the increasing emphasis on water-quality issues, as well as on other concerns regarding the availability and distribution of the resource. The water-quality issues include aquifer contamination, effects of acid rain, river-quality assessment, effects of storm runoff, and the effects of agricultural chemicals and practices on ground and surface water.

The Geological Survey has included water-quality activities in its programs virtually from the time it was established. Until 10 years ago, most of the Geological Survey's emphasis on contamination concerns was concentrated in the Federal-State Cooperative Program. The effects of urban and agricultural runoff, saltwater intrusion, acid precipitation, industrial and sewage discharges, and the underground storage of wastes, for example, were topics of local urgency and were being investigated long before their emergence as problems of national importance.

The Nation's ability to cope with new and challenging problems in ground-water development and management rests in large measure on information from investigations made in the Cooperative Program. Historically, ground water was studied almost entirely through this program. As a result many of the major scientific advances achieved by the pioneers in hydrology were also the direct result of work conducted in this program. Following is a list of selected national groundwater issues and examples of where and when they were first identified as part of the Cooperative Program. 


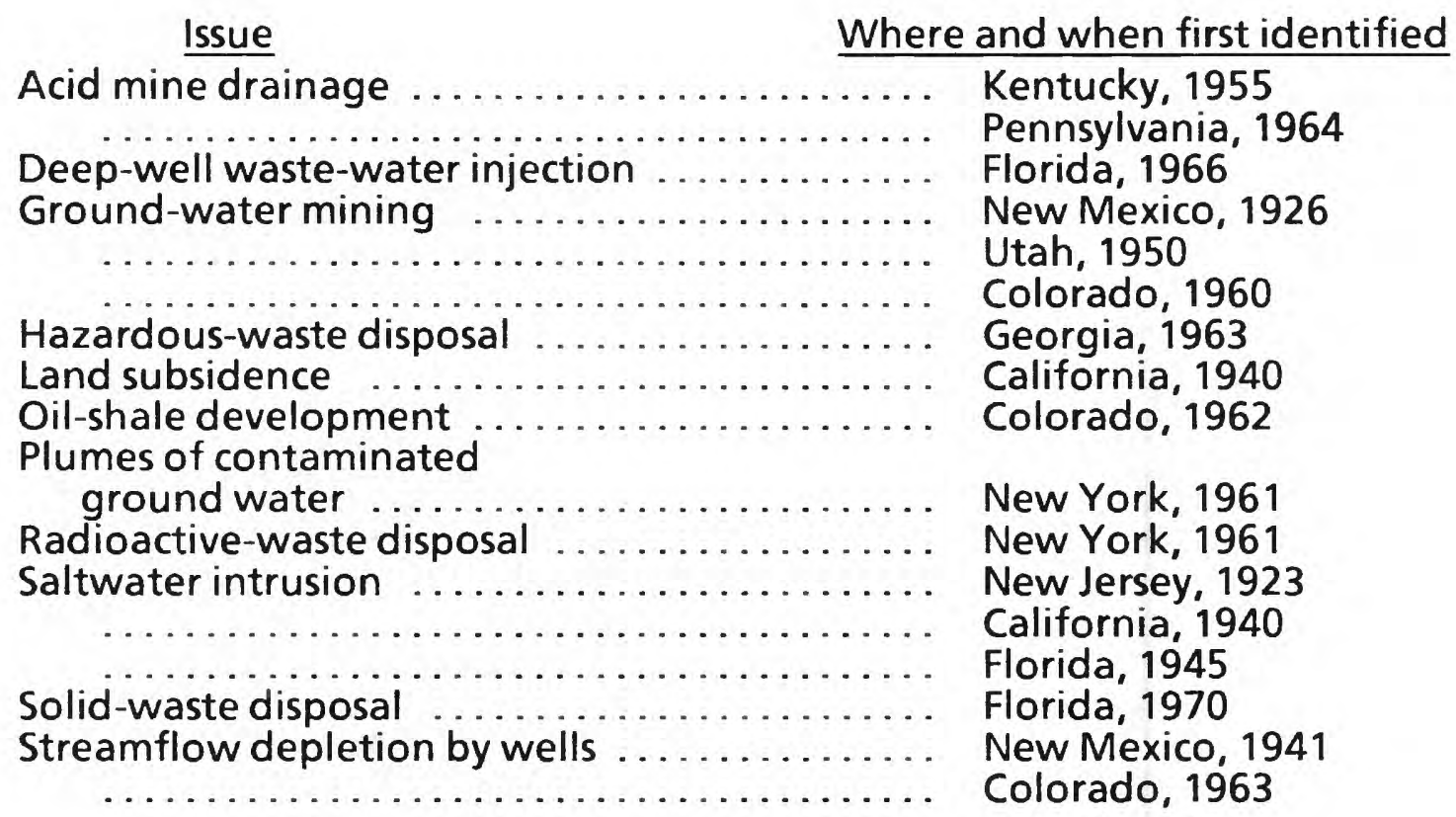

The program priorities for FY 1989 have not changed greatly from those of the past several years. Water-quality issues again head the list. Approximately three-fourths of the investigations undertaken in the Cooperative Program will in part address ground- or surface-water quality. Of these, it is estimated that more than one in four will focus on contamination problems.

The following issues have been identified as highest priority in developing the FY 1989 Cooperative Program:

Ground-Water Quality--Concern over the quality of the Nation's ground-water resources is creating increasing demands for studies relating to both protection of available supplies and remediation of existing contamination problems. Studies are needed to define present water quality as a baseline for evaluating future changes and for implementing programs to protect the ground-water resource. Of equal importance are studies of the movement and fate of contaminants in ground-water systems. Studies will address flow dynamics and solute-transport processes with emphasis on those geochemical processes that influence the suitability of water for use -- particularly those uses that could affect human health. These include natural processes as well as those related to human activities that act to alter, add, or remove contaminants. Also needed are studies of the environmental effects of waste disposal, contamination by nonpoint sources, and saltwater encroachment.

Stream Quality--Appraisals of the water quality of the Nation's streams continue to be a high-priority need both in areas where contamination has been documented and in areas where contamination may or may not be a problem. Studies are needed of stream quality and sediment chemistry as related to land-use and land-use changes, stream biota, ground-water contribution of contaminants, and overland runoff. Particular emphasis will be given to the occurrence and transport of toxic substances and the impact of contamination on the stream environment.

Water Supply and Demand--Increasing diversion, withdrawal, and use of water places stress on the quantity and quality of existing supplies, thereby raising costs of 
delivery and treatment and presenting ever more difficult problems of allocation and quality management. Information defining present water use is required to quantify such stresses over time and space. Topical studies are needed to improve estimates of water use in categories outlined in the National Water-Use Program. Emphasis also must be placed on the identification of aquifers that are major sources for water supply. Topics for study will include streamflow response to drought conditions and system response both to projected uses and supply-augmentation schemes.

Hydrologic Hazards--Economic losses from floods, droughts, rising lake levels, mudflows, debris flows, sedimentation, and other hydrologic hazards amount to billions of dollars annually in addition to loss of life. These hazards are related not only to meteorological conditions, but also to such phenomena as landslides, volcanic eruptions, and earthquakes. Studies are needed to define the magnitude and probability of occurrence of hazardous hydrologic events and to improve understanding of the processes that cause them.

Wetlands, Lakes, and Estuaries--These valuable ecosystems deserve special consideration because of their importance as habitats for fish and wildlife, sources of water supply, and recreational activities. These areas are particularly sensitive to human encroachment, but increasingly function as sinks for waste products. Studies will address the availability, movement, and quality of water including surfacewater/ground-water interactions. Emphasis will be placed on physical, chemical, and biological processes, particularly on waste-assimilation studies.

Hydrometeorological Effects--Scientific evidence is accumulating regarding the effects of man's activities on the chemical composition of the Earth's atmosphere and consequent effects on the worldwide hydrologic regimen. Specific issues of immediate concern include acid precipitation, airborne transport and deposition of toxic substances, changing ocean and lake levels, and long-term climate change. Studies of the effects of the chemistry of precipitation on stream quality and the interaction of acid rain with biological systems will continue to receive priority attention in terranes that have limited ability to buffer ground and surface waters, and in urban settings that produce large loads of atmospheric pollutants. In addition to the damage associated with rising lake levels, other issues will include extreme fluctuations in water availability and water-quality changes resulting from intrusion of saltwater or other highly mineralized water.

Hydrologic Effects of Fossil Fuel and Mineral Extraction--The mineral extraction industries, oil and gas production and processing, solid-fuel mining and processing (such as coal and oil shale), and metallic and nonmetallic mining, greatly affect hydrologic systems. Effects may relate to a wide spectrum of hydrologic phenomena, including interaction of subsurface fluids having different chemical and physical characteristics, large-scale aquifer dewatering to permit mining, disruption of surface drainage, and disturbance of geochemical equilibria. Investigations will include studies of the hydrologic effects of land reclamation, mining, and waste disposal. 
The U.S. Geological Survey's Federal-State Cooperative Water-Resources Program (50:50 matching of funds) has responded to national needs for hydrologic information since 1895. During FY 1988, water-resources data collection, investigations, and research were conducted in cooperation with more than 1,000 local, State, and regional agencies in every State, Puerto Rico, and several territories. Total funding in FY 1988 amounted to about $\$ 126$ million and accounted for more than 40 percent of the total obligations for the Geological Survey's Water Resources Division. The Cooperative Program provides much of the information required by those responsible for water-resources planning and management, water-supply development, and environmental improvement through hydrologic data collection, investigations, and research. The program is a unique activity in that, although the cooperating agencies provide more than half the funds, the Geological Survey accomplishes most of the work with a nationwide staff of about 4,000 scientists, engineers, and support personnel. The program also is the source of much of today's knowledge concerning techniques for collection and analysis of the quantity, quality, and movement of surface and ground water.

Water-resources data collection and investigations related to agricultural activities have been conducted by the Geological Survey since the time it was founded. From 1970 through 1988, about 250 such investigations were underway of which about 70 percent were part of the Federal-State Cooperative Program. The number of agriculture-related investigations with ground-water components increased from 40 in 1983 to 66 in 1988 . This growth is indicative of the mounting national concern of the relation between agricultural activities and ground-water quality.

Because the availability of water of suitable quality is a fundamental limiting factor in an expanding economy, a comprehensive and forward-looking data-collection and investigation operation is imperative for planning the best development and use of the Nation's water resources. The job is too large to be supported at either Federal or State level alone. The jointly planned and funded Cooperative Program provides convincing assurance that the work is designed to meet both national and local needs. 


\section{REFERENCES CITED}

Davis، A. P., 1897, Irrigation near Phoenix, Arizona: U.S. Geological Survey WaterSupply Paper 2, 98p.

Gianessi, L. P., 1987, Lack of data stymies informed decisions on agricultural pesticides: in Resources, journal of Resources for the Future, No. 89, Fall 1987. ISSN 0048-7376, p. 1-4.

Gilbert, B.K., Mann, William B. IV, and Emery, P.A., 1987, Some Aspects of U.S. Geological Survey Activities Related to the Effects of Contaminants on Water Resources: U.S. Geological Survey Open-File Report 87-574,63p.

Gilliom, R. J. , 1985, Pesticides in rivers of the United States: p. 85-92, in U.S. Geological Survey, 1985, National Water Summary 1984: U.S. Geological Survey Water Supply Paper 2275, 467p.

Madison, R. J. and Brunett, J. O., 1985, Overview of the occurrence of nitrate in ground water of the United States, p.93-105, in U.S. Geological Survey, 1985, National Water Summary 1984: U.S. Geological Survey Water Supply Paper $2275,467 p$.

Rafter, G. W., 1897, Sewage irrigation: U.S. Geological Survey Water-Supply Paper 3, $100 \mathrm{p}$.

Solley, W. B.,, Merk, C. F., and Pierce R. R., 1988, Estimated use of water in the United States in 1985: U.S. Geological Survey Circular 1004, 82p.

Wilson, H. M., 1896, Pumping water for irrigation: U.S. Geological Survey WaterSupply Paper 1,57p.

U.S. Geological Survey, 1984, National water summary 1983--Hydrologic events and issues: U.S. Geological Survey Water-Supply Paper 2250, 243 p.

U.S. Geological Survey, 1985, National water summary 1984--Hydrologic events, selected water-quality trends, and ground-water resources: U.S. Geological Survey Water-Supply Paper 2275, 467 p.

U.S. Geological Survey, 1986, National water summary 1985--Hydrologic events and surface-water resources: U.S. Geological Survey Water-Supply Paper 2300, $506 \mathrm{p}$.

U.S. Geological Survey, 1988, National water summary 1986--Hydrologic events and ground-water quality: U.S. Geological Survey Water-Supply Paper 2325, 560p. 


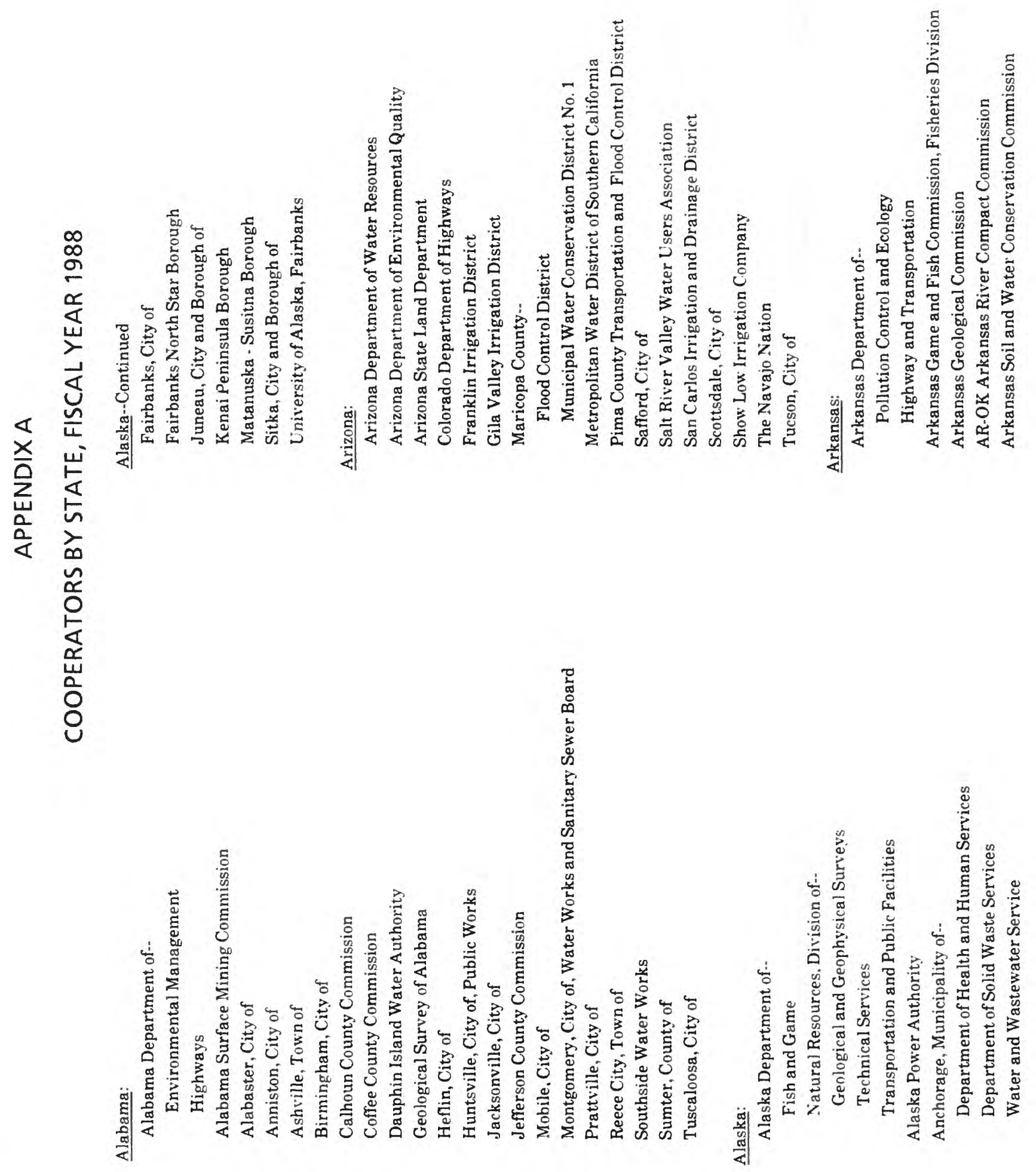



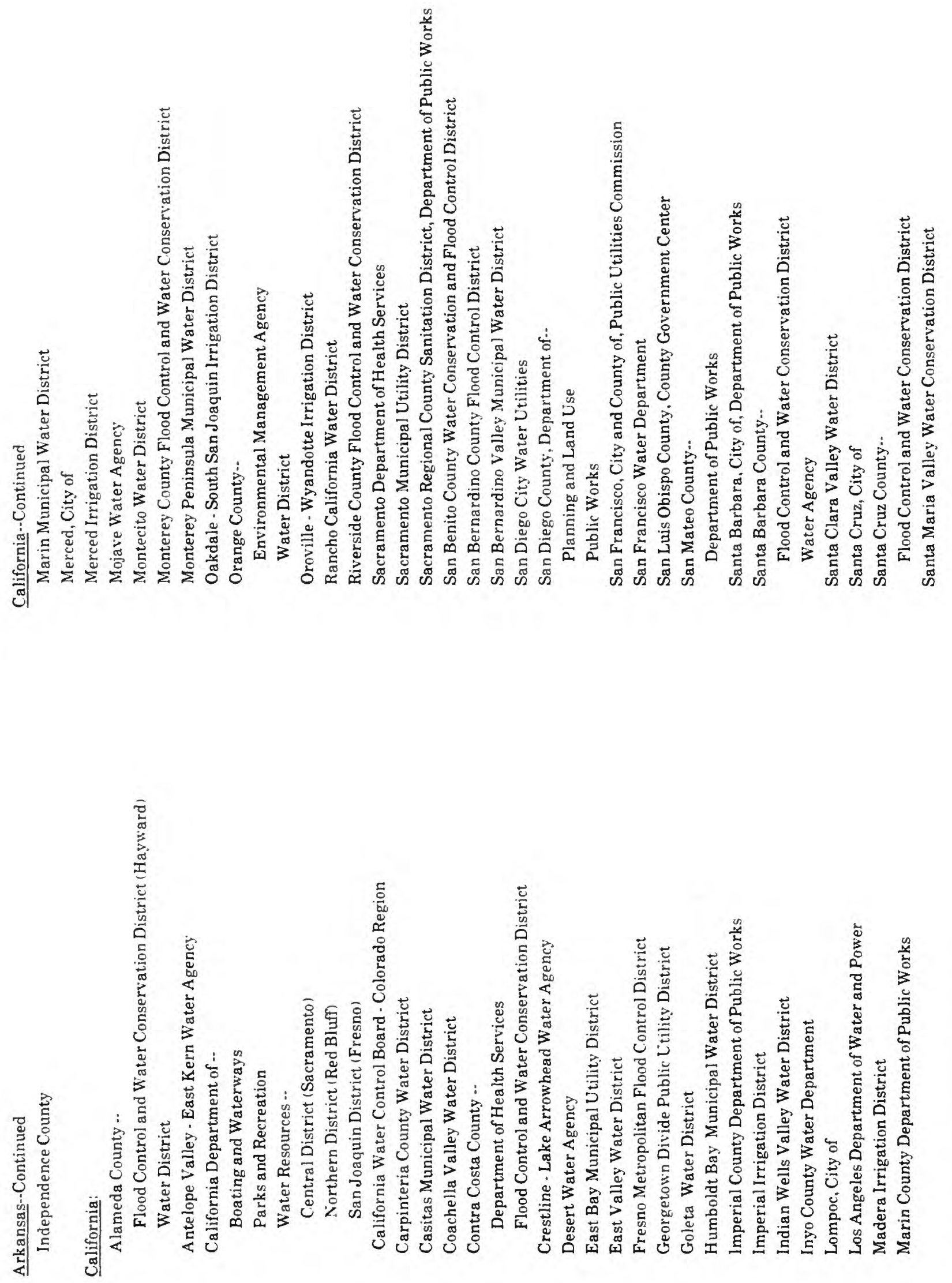

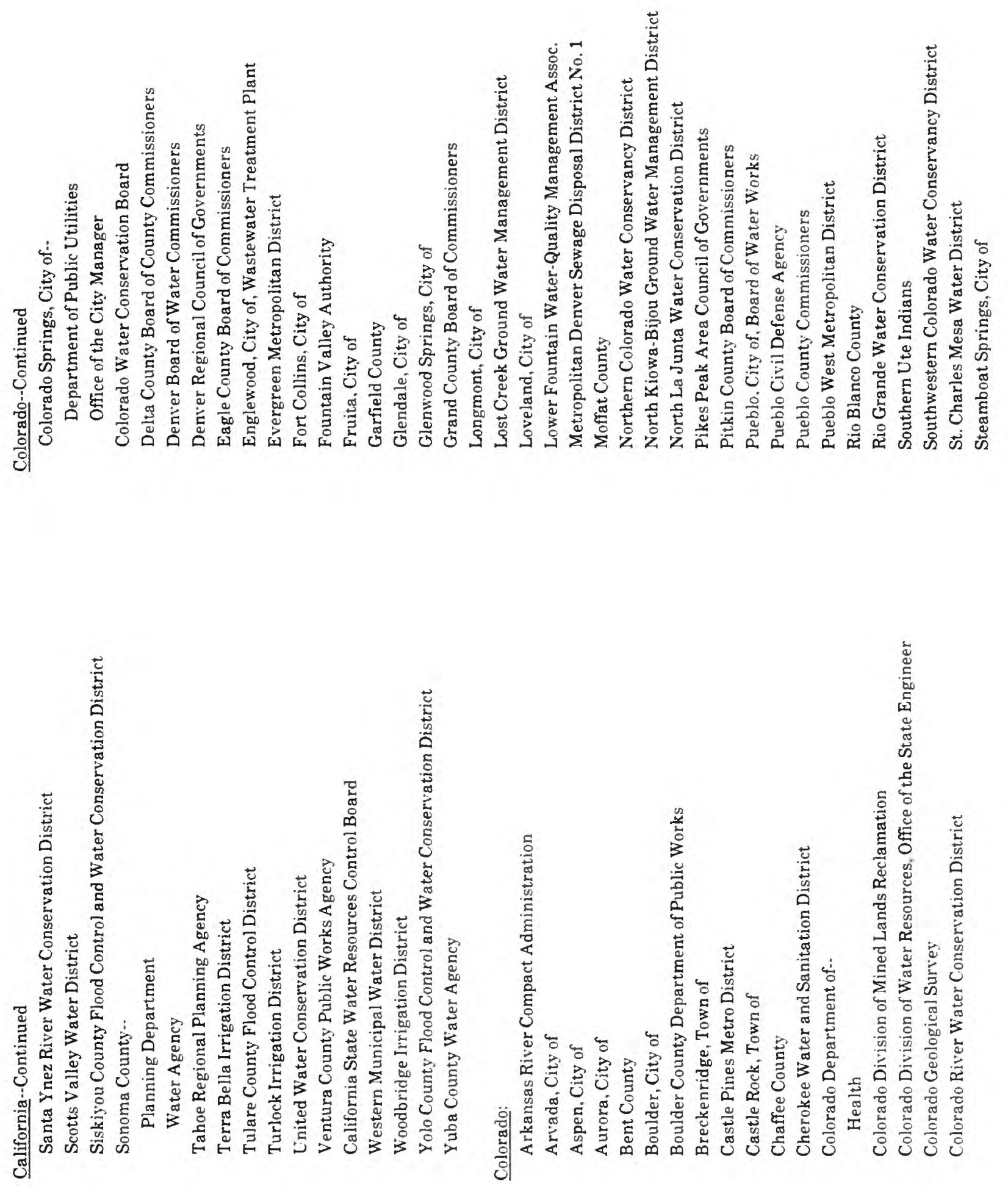

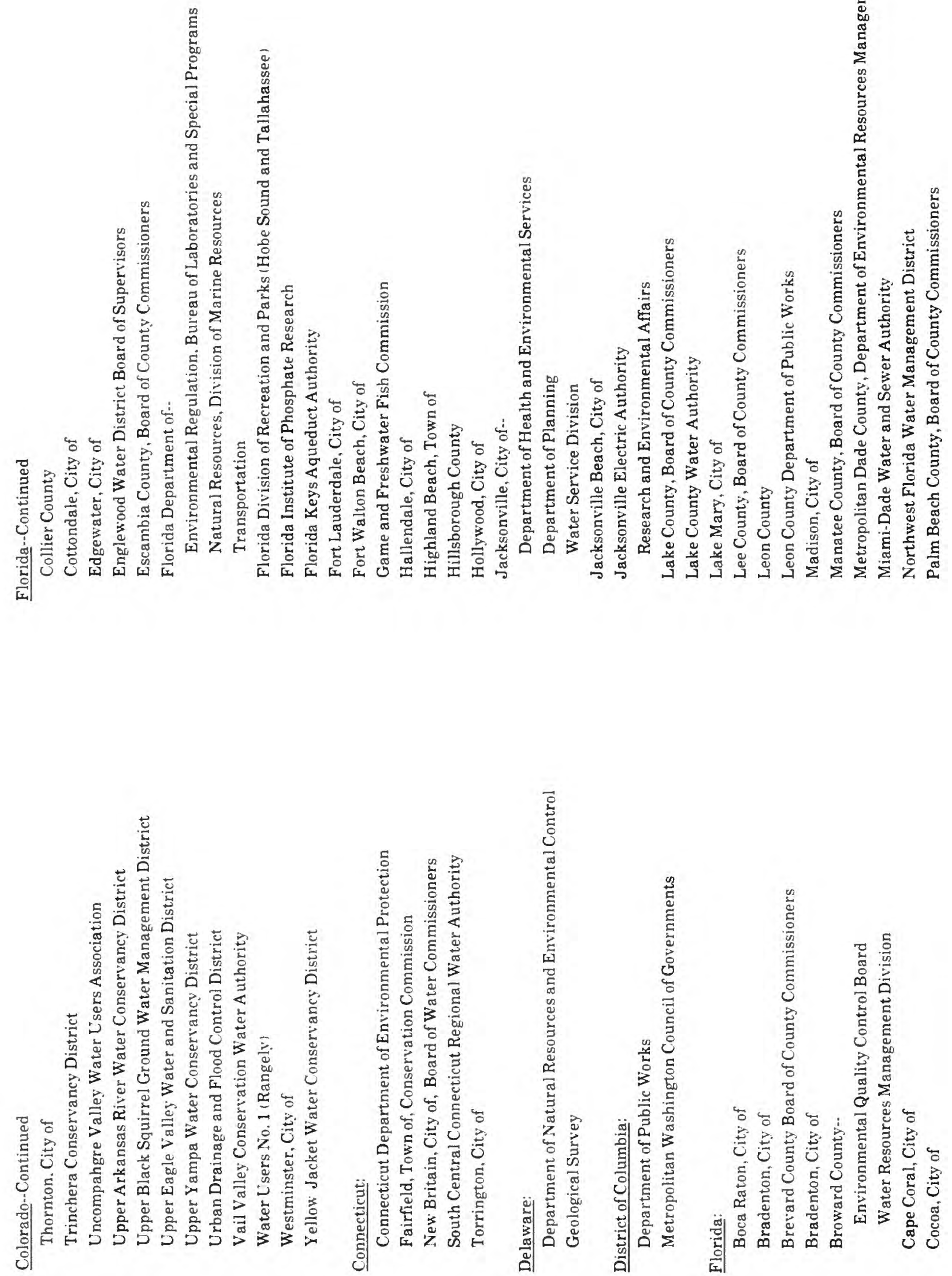

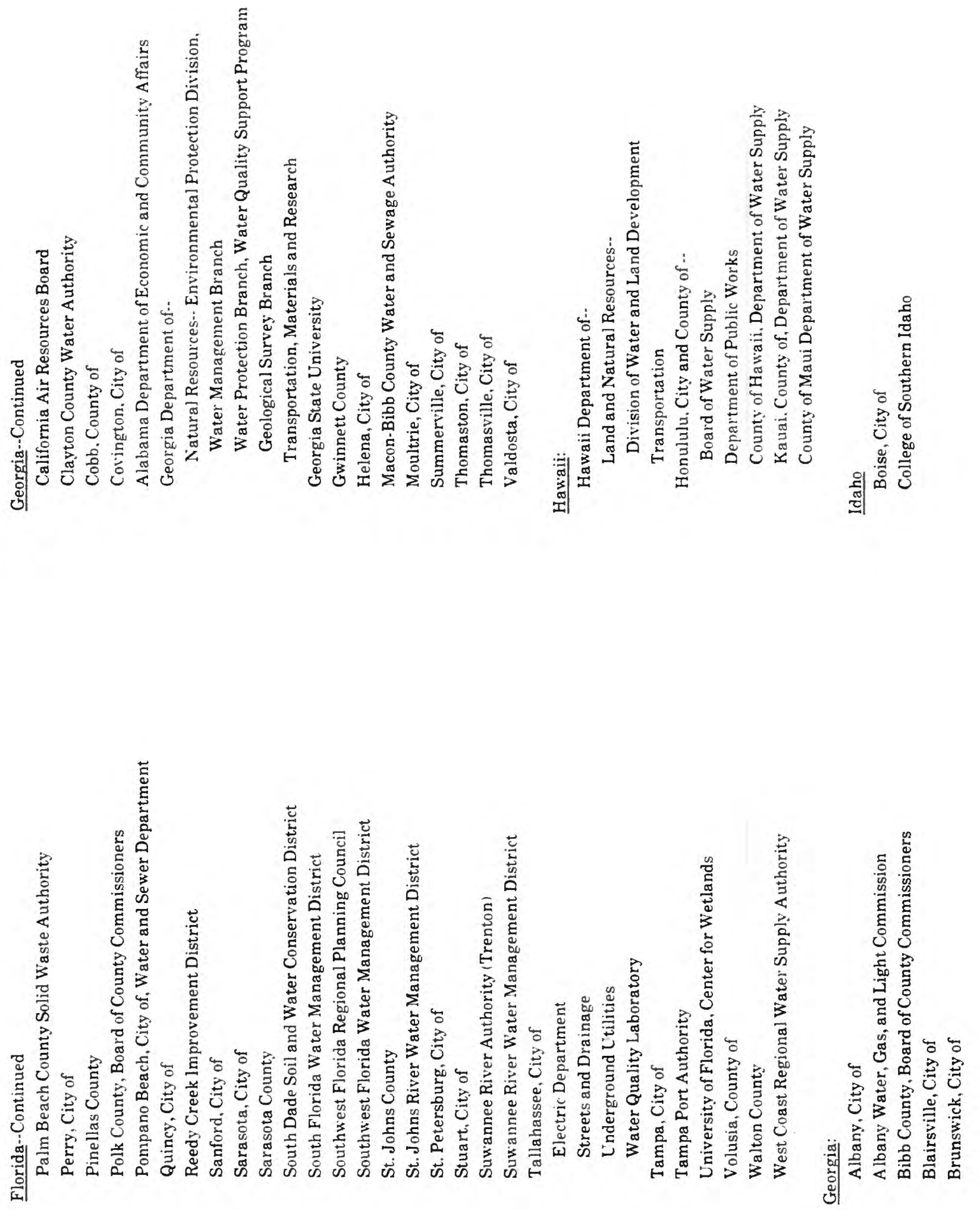

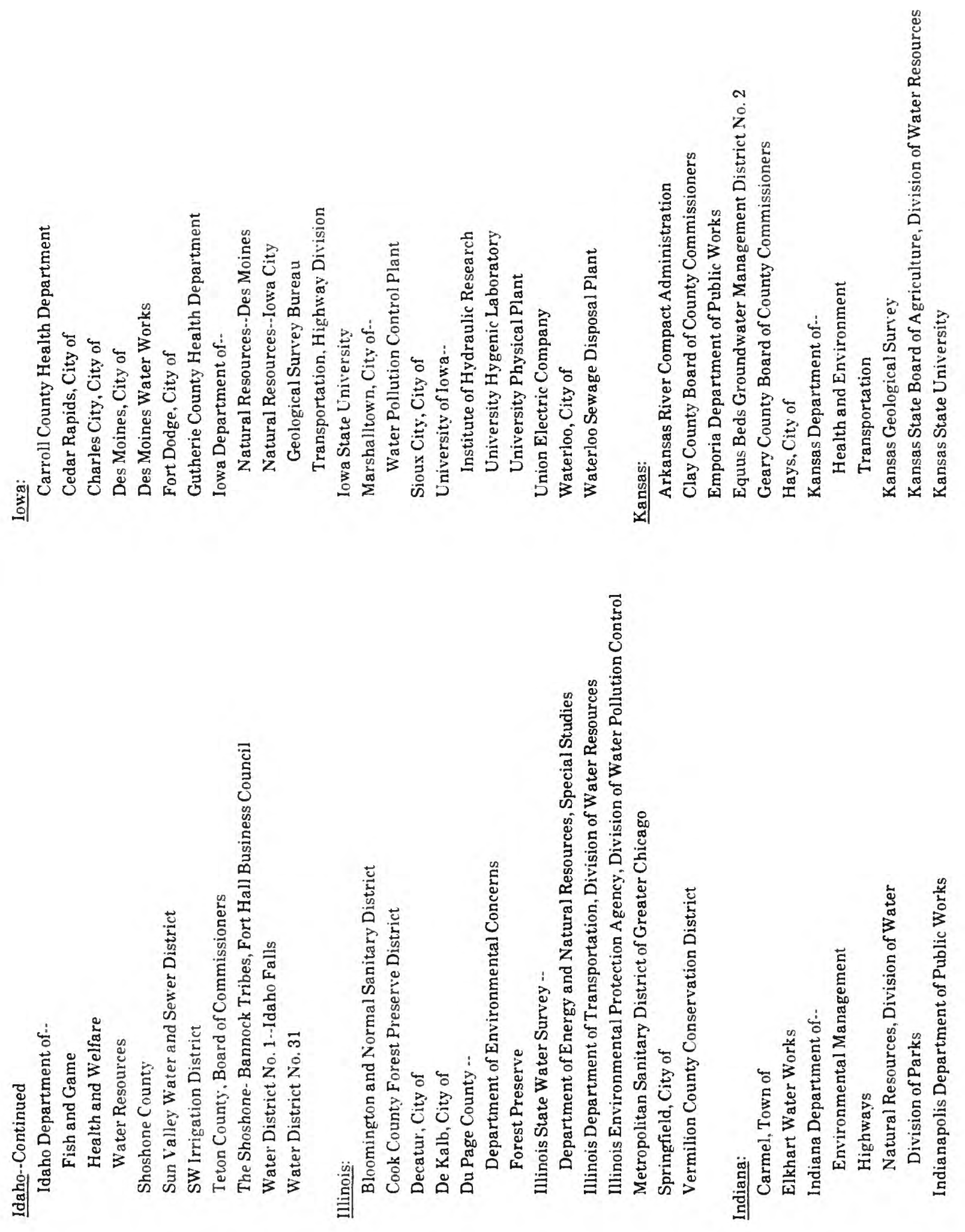

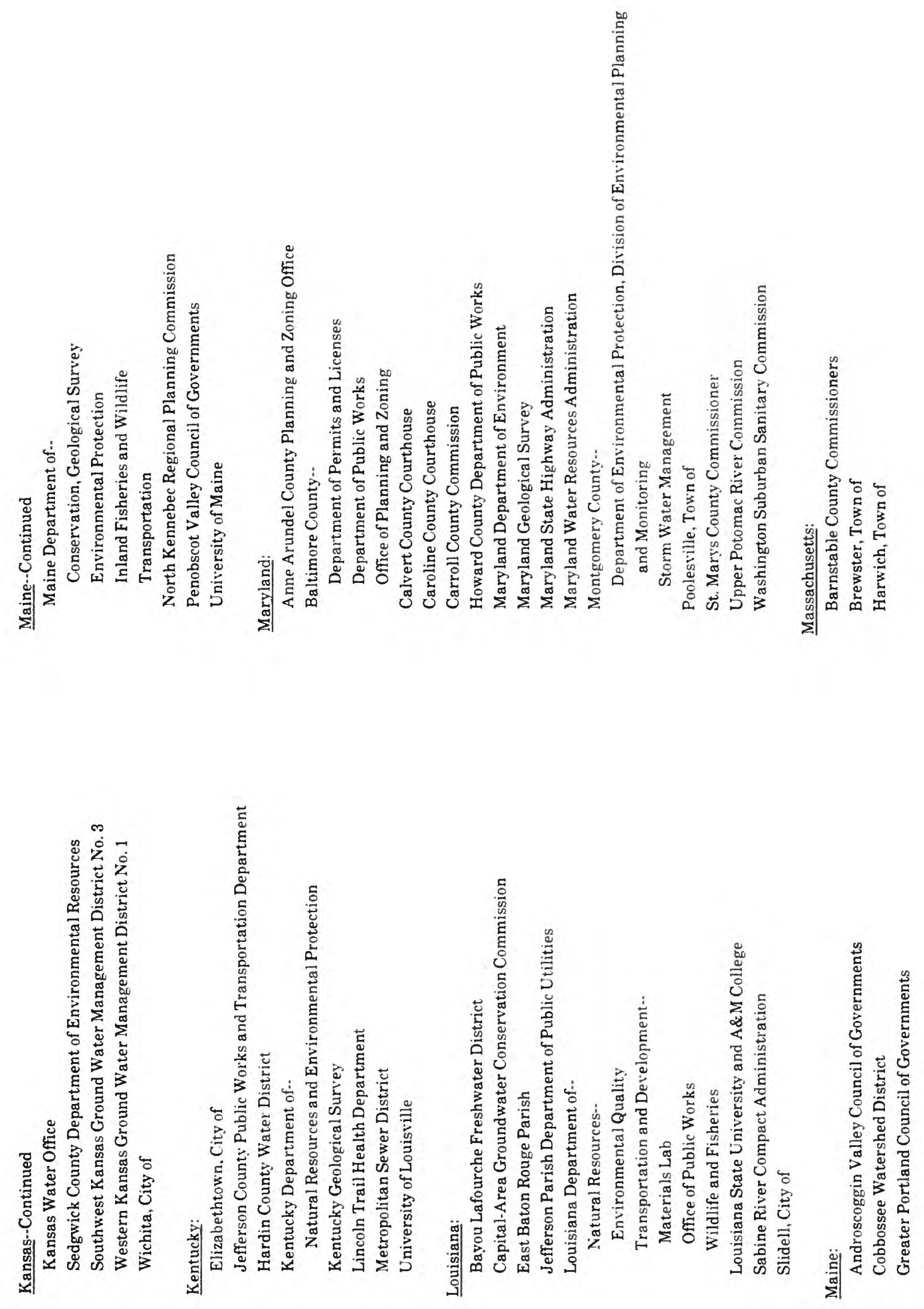

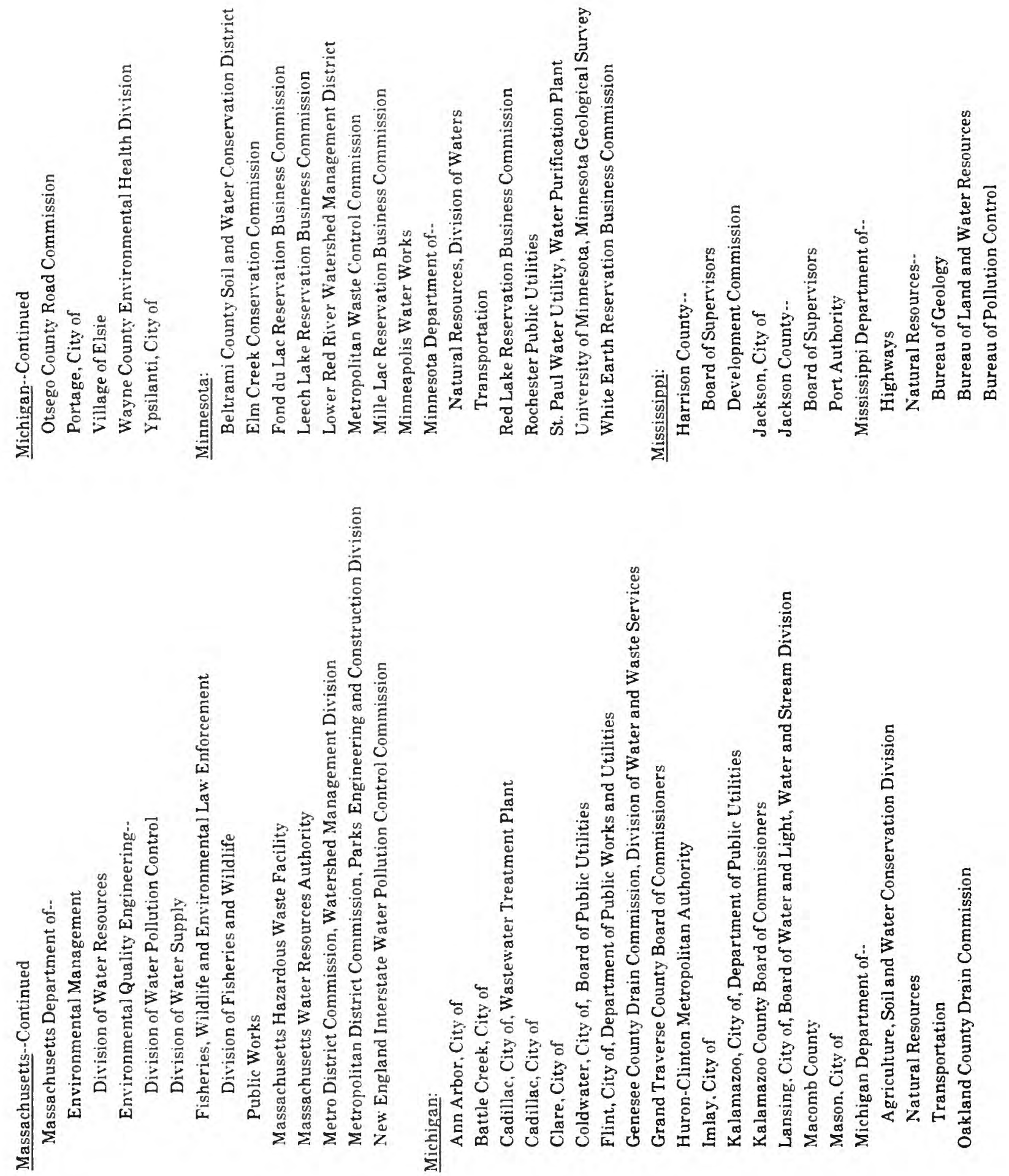

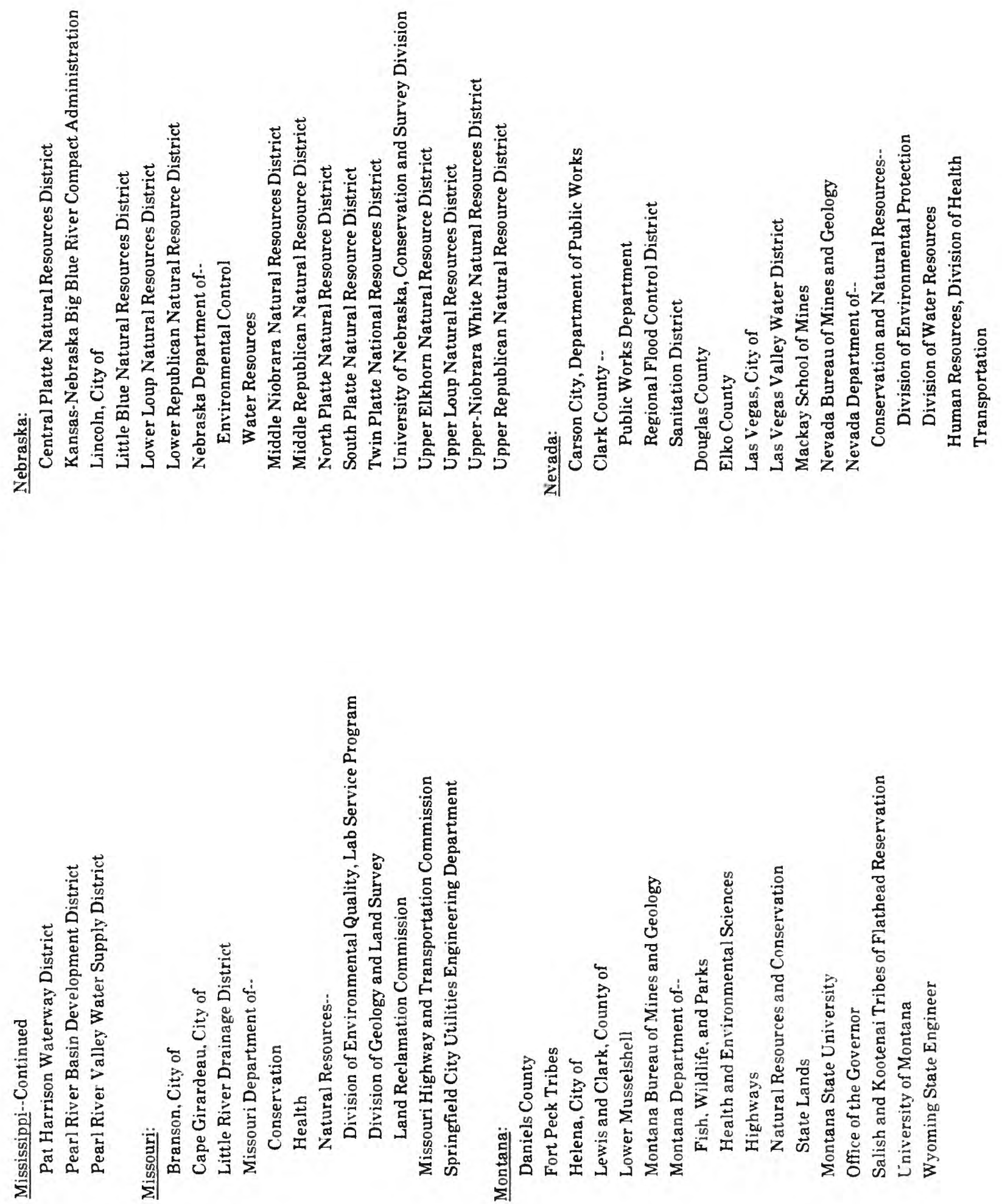

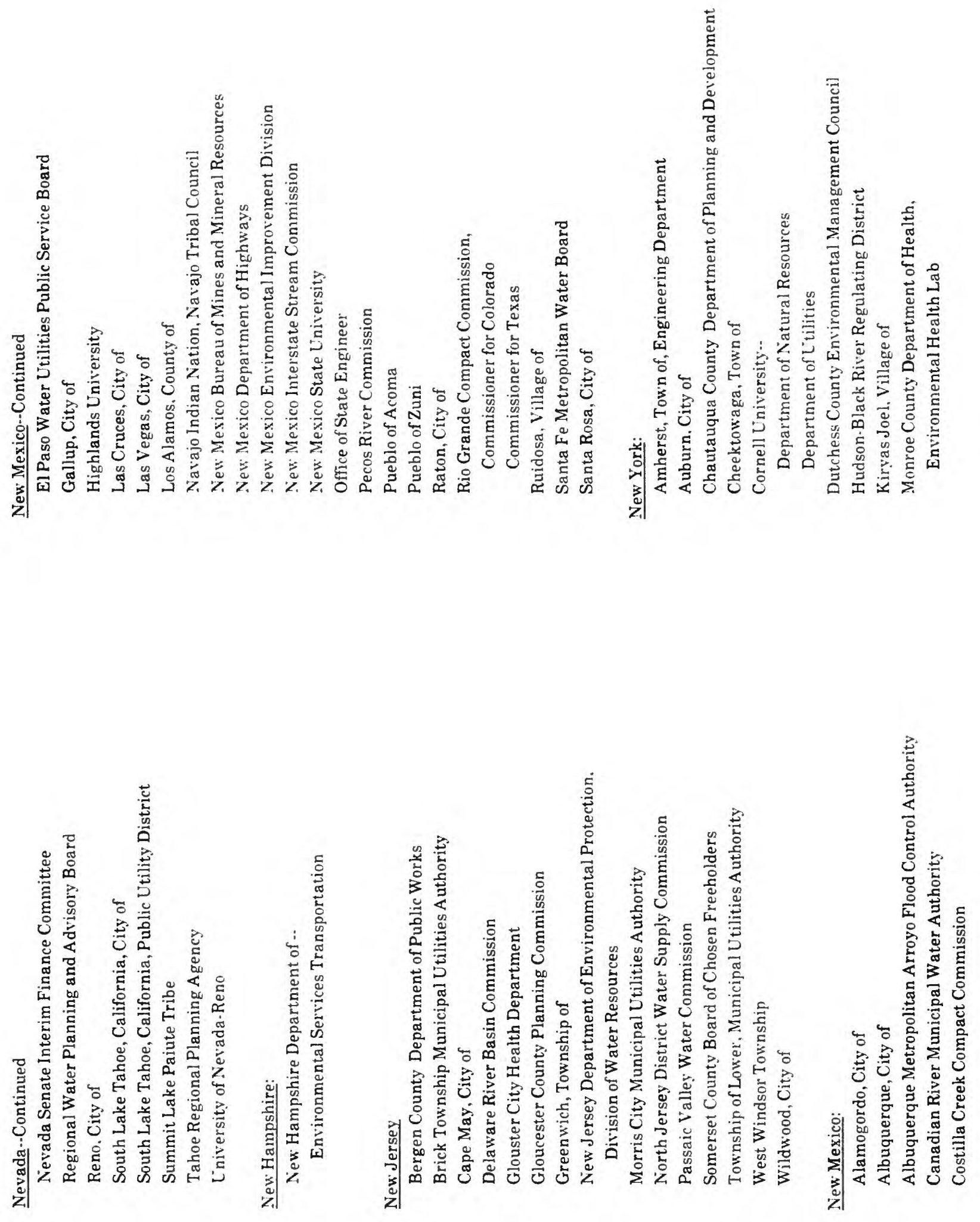

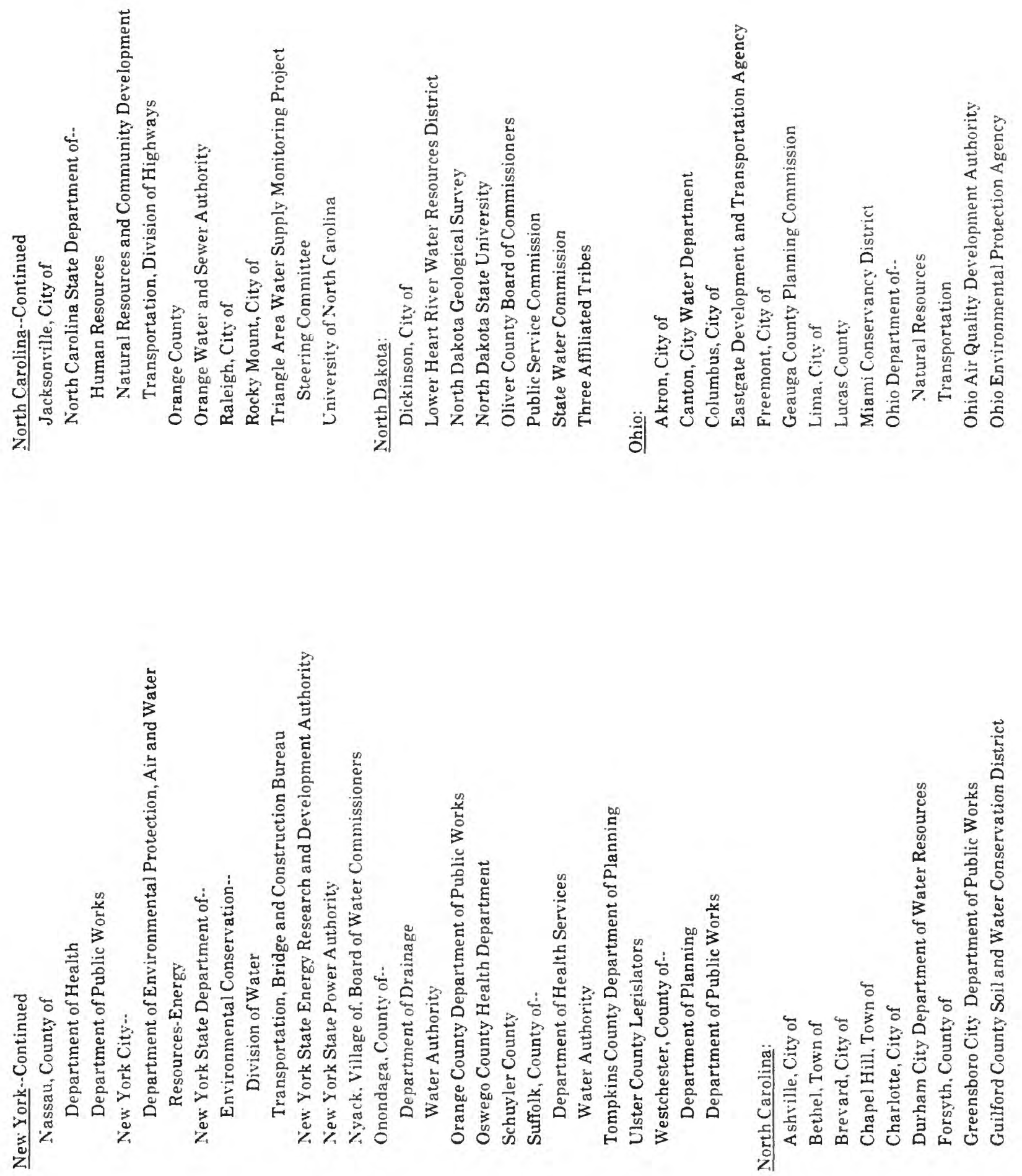

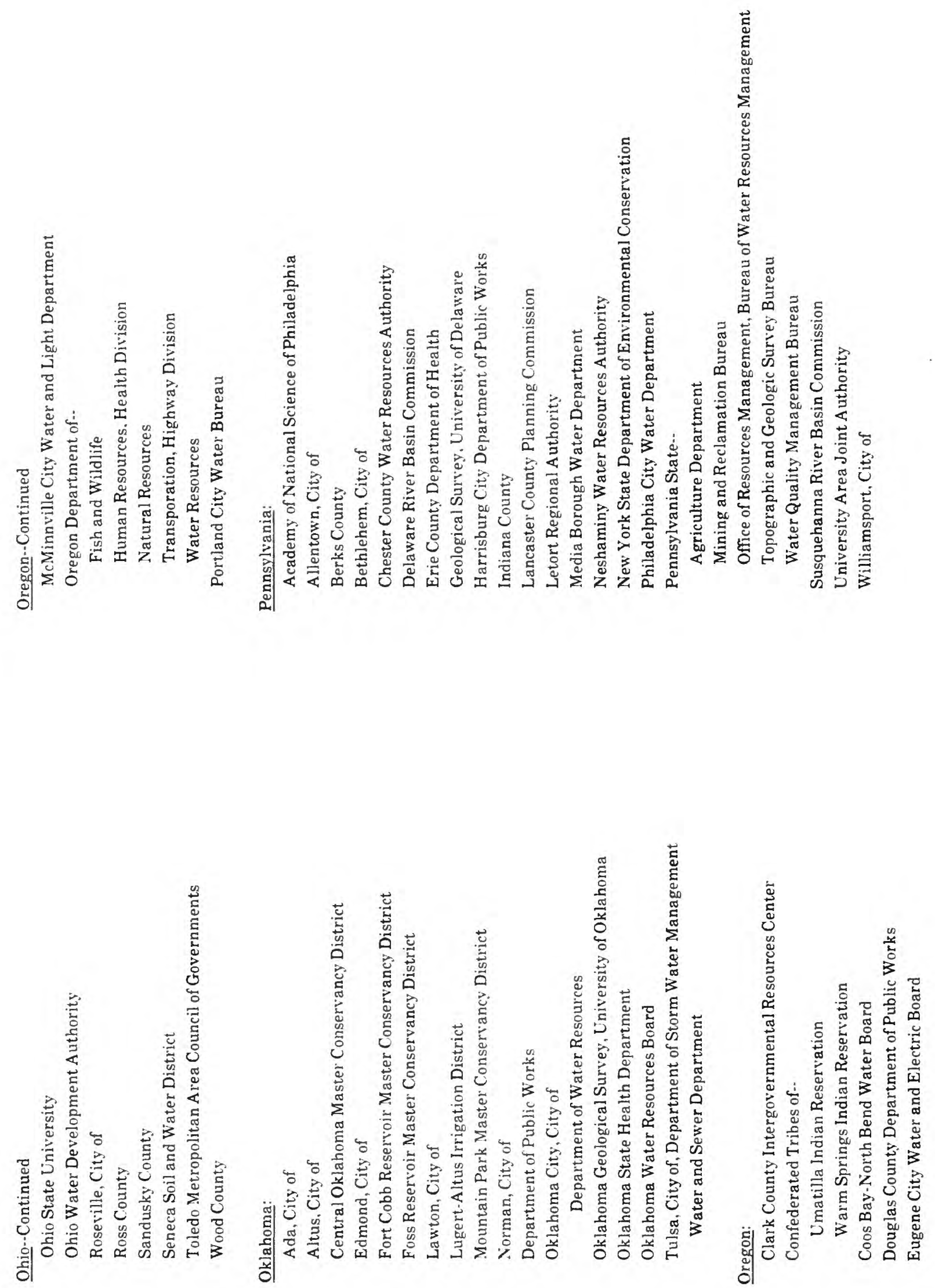

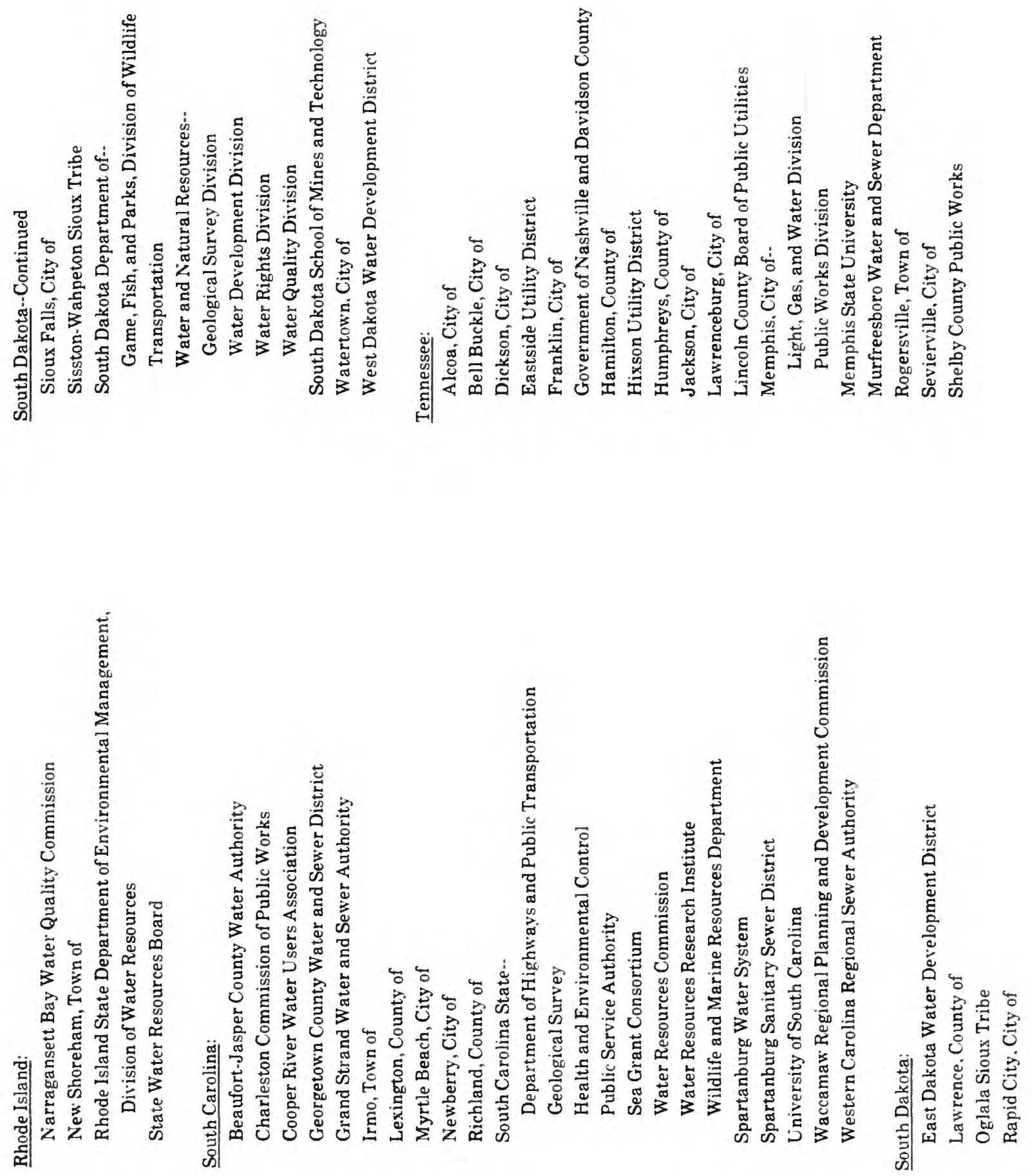

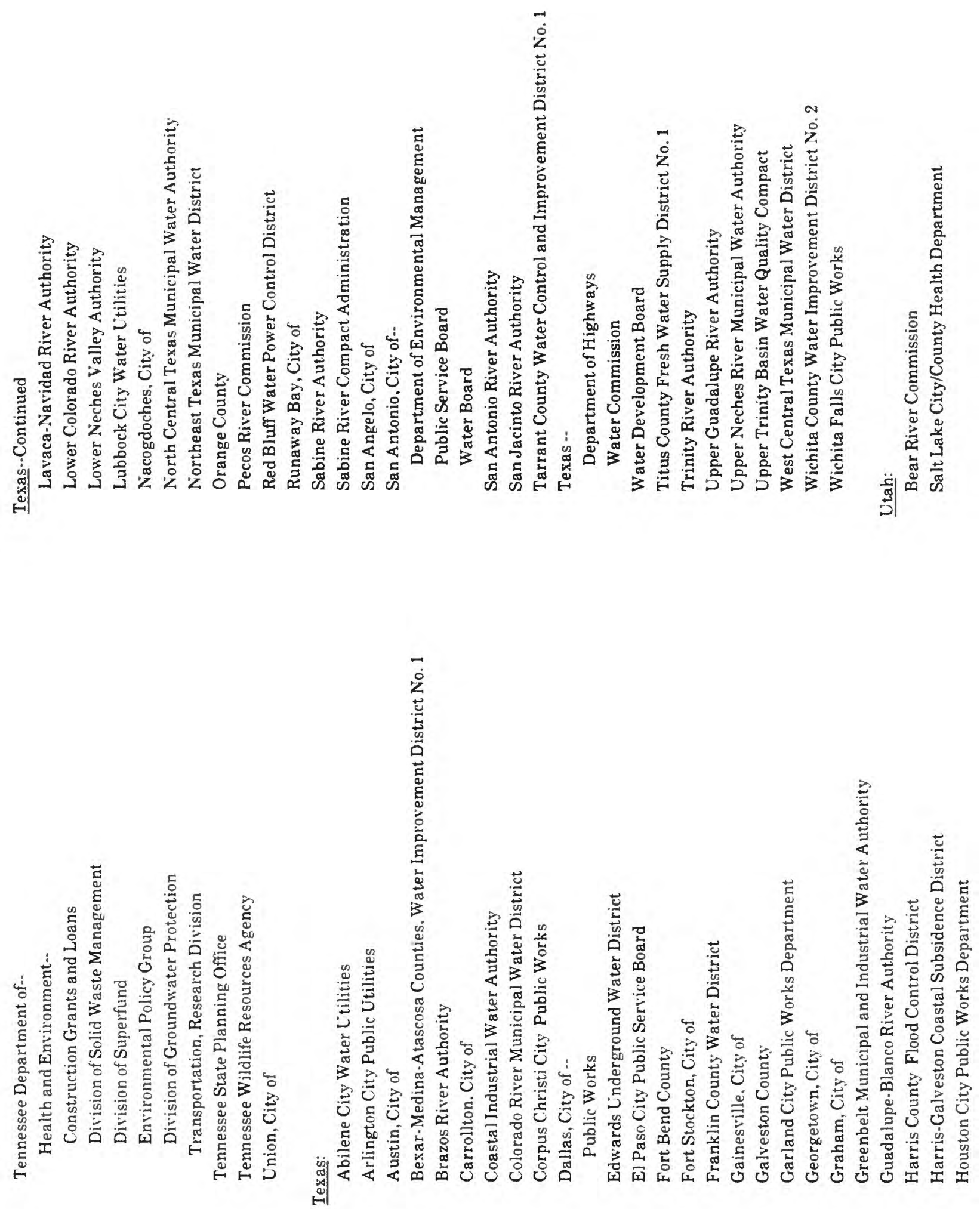

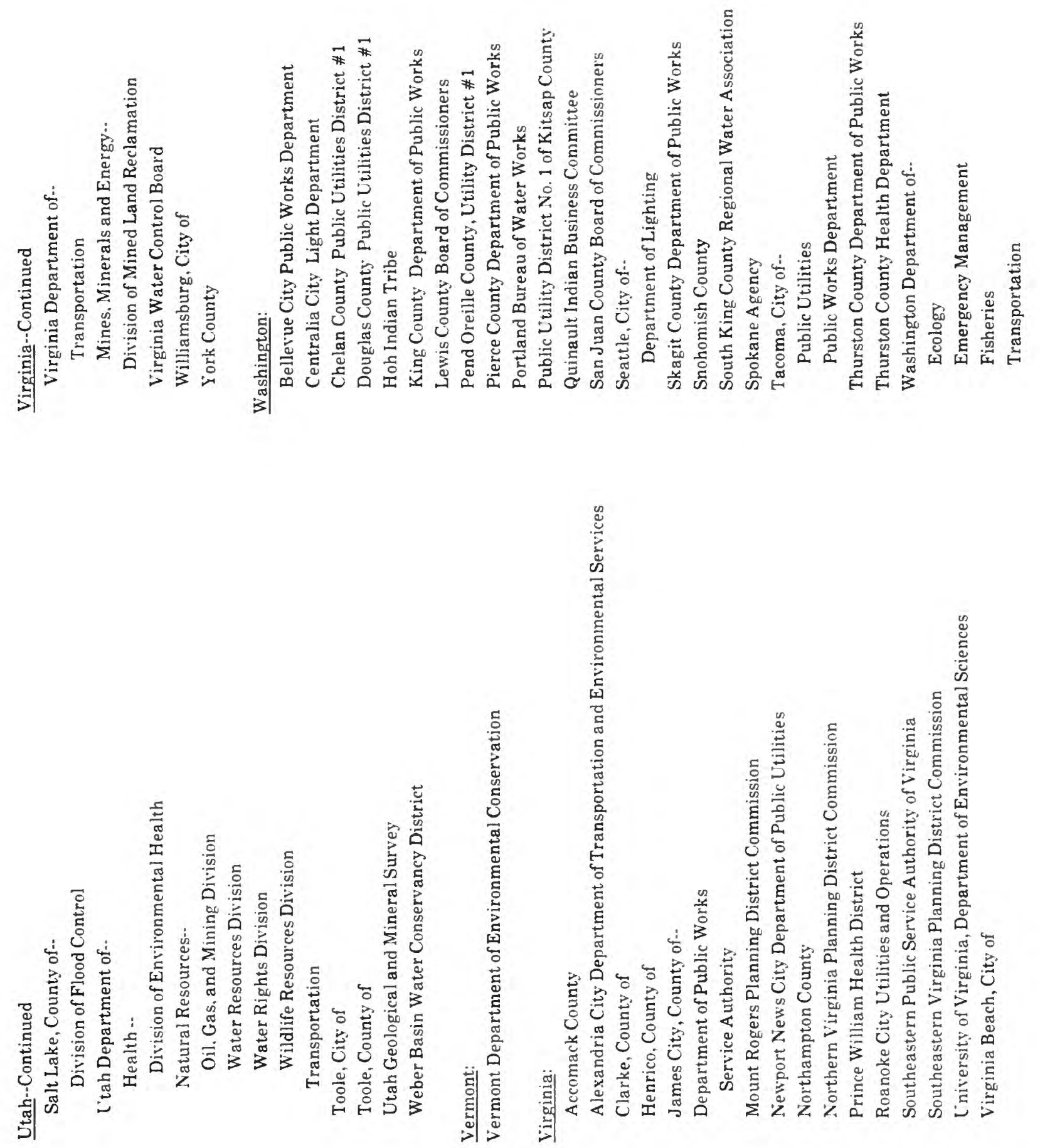

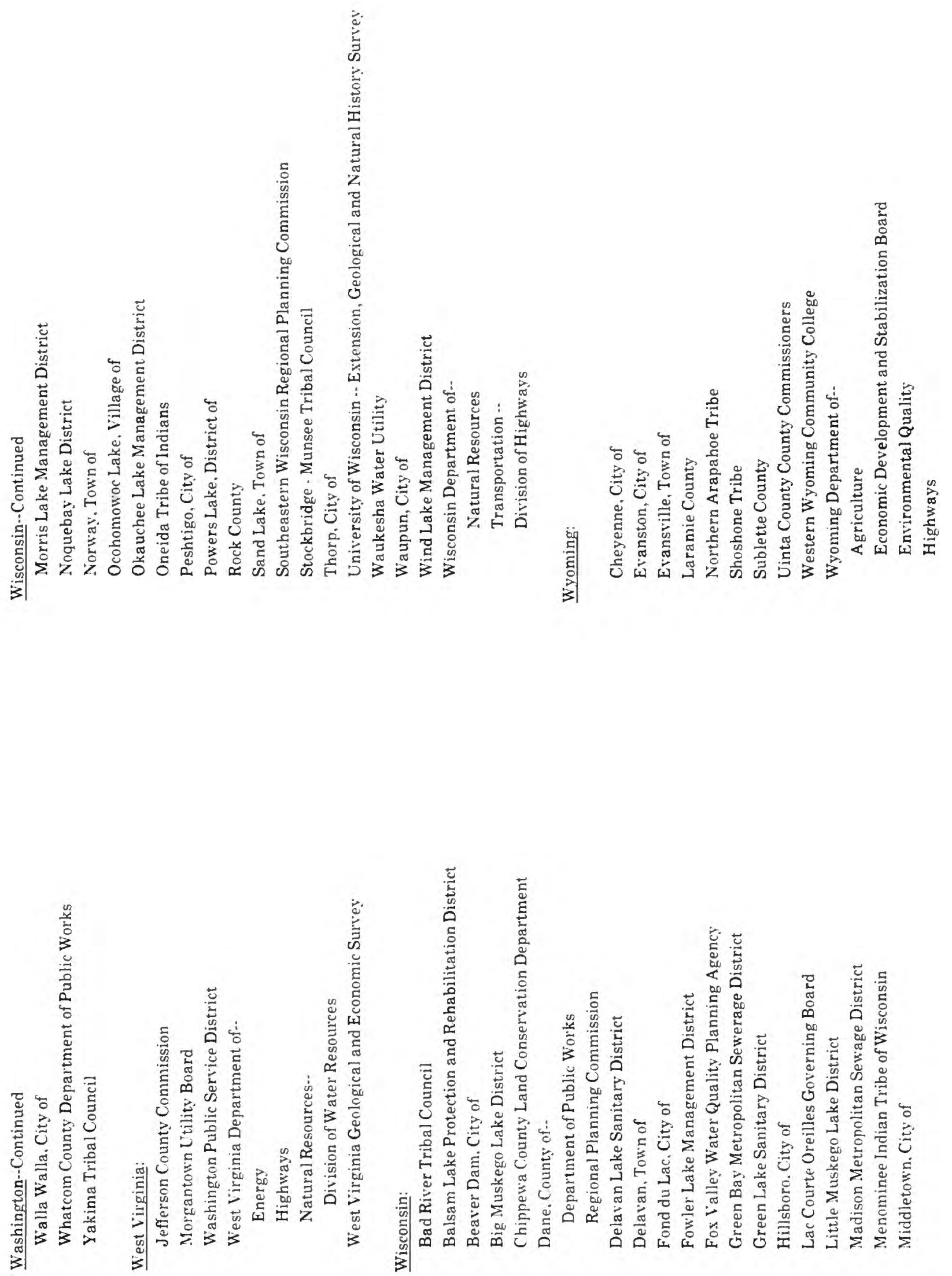


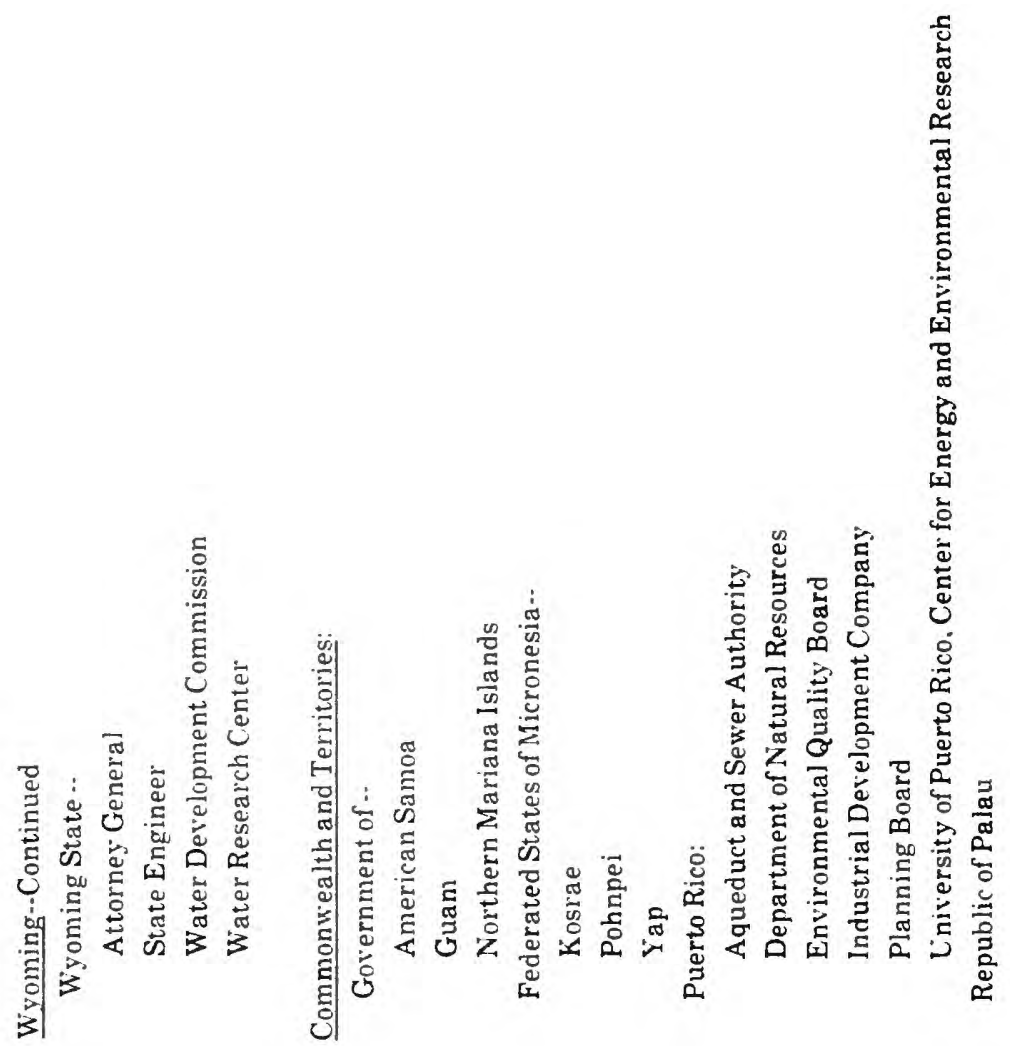




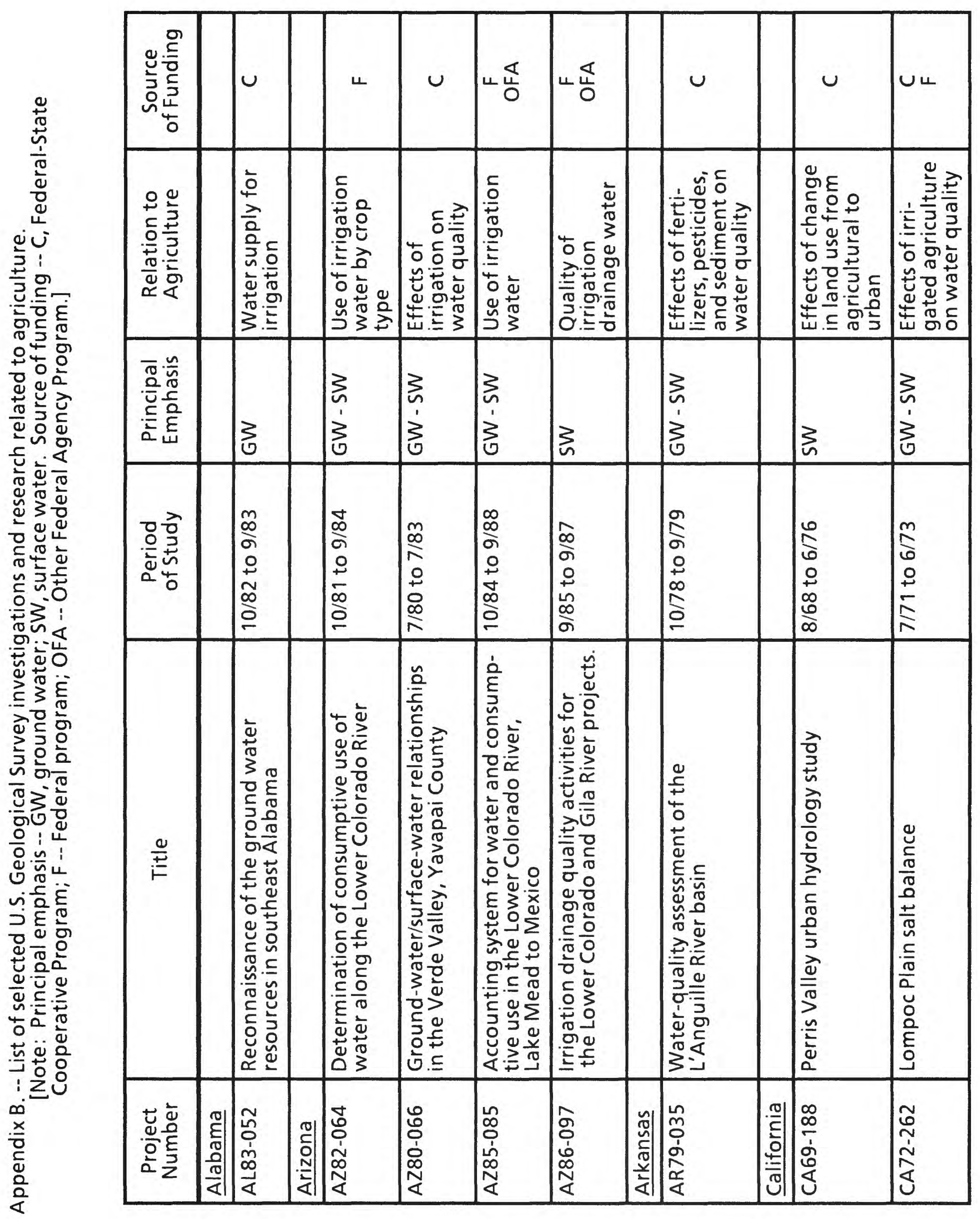




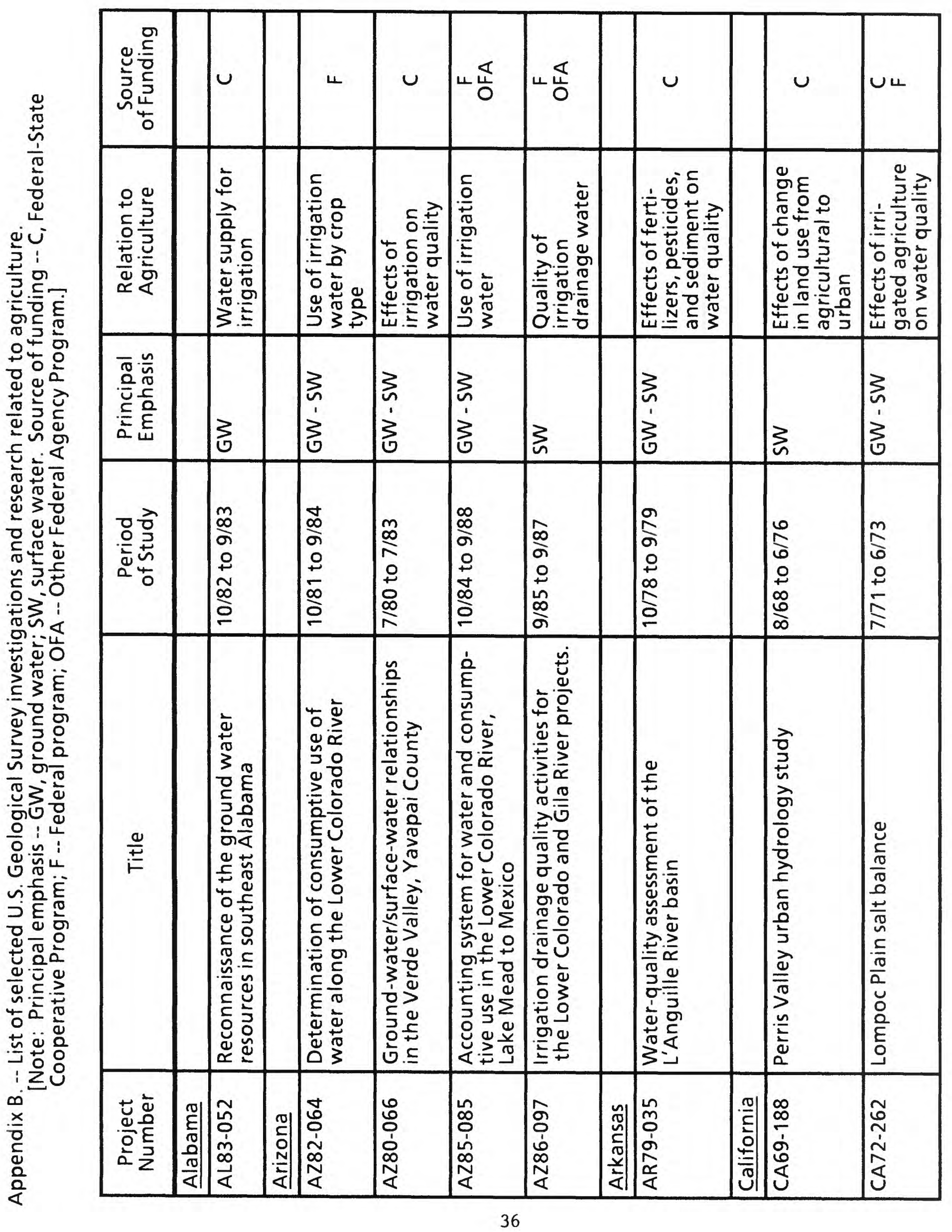




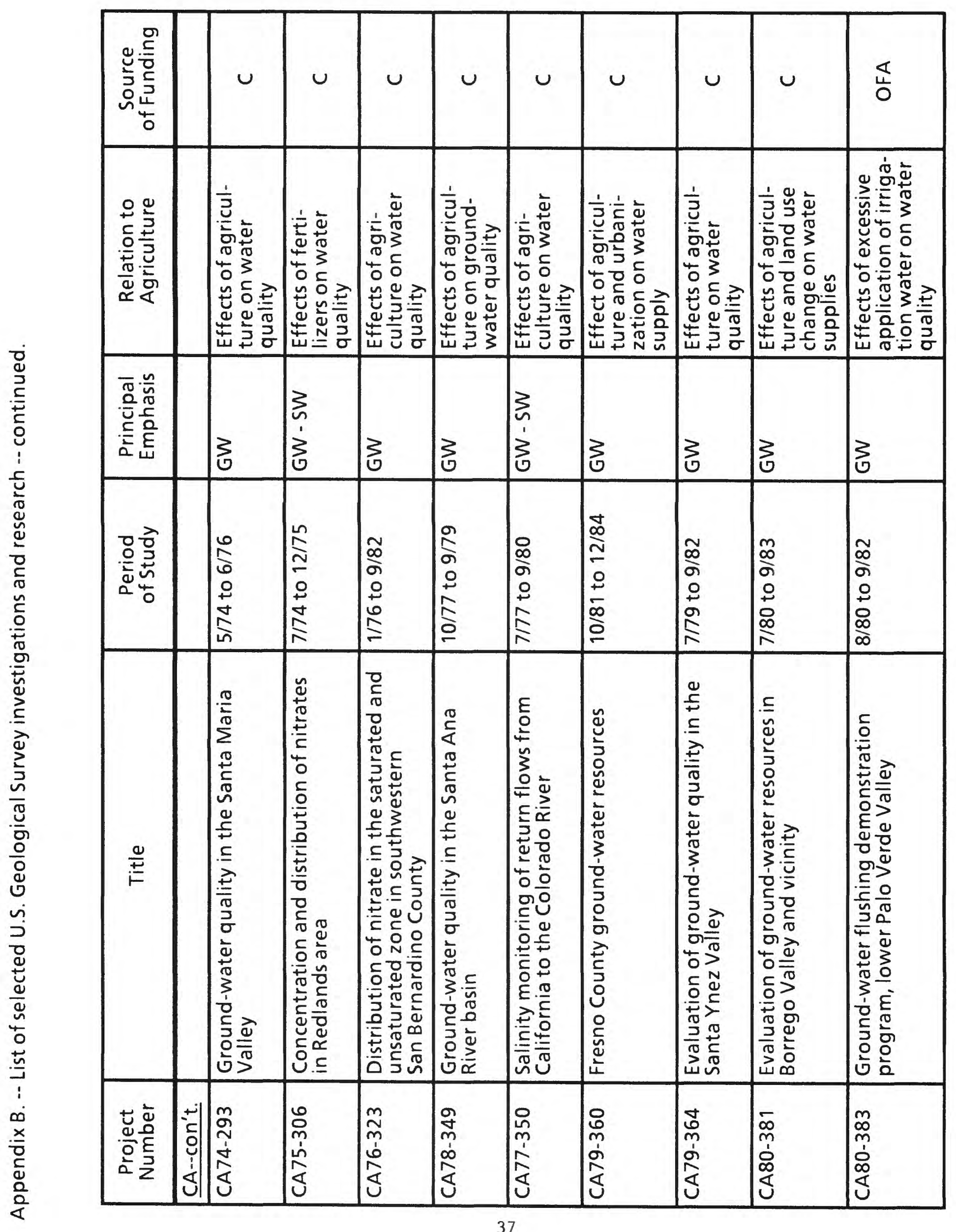




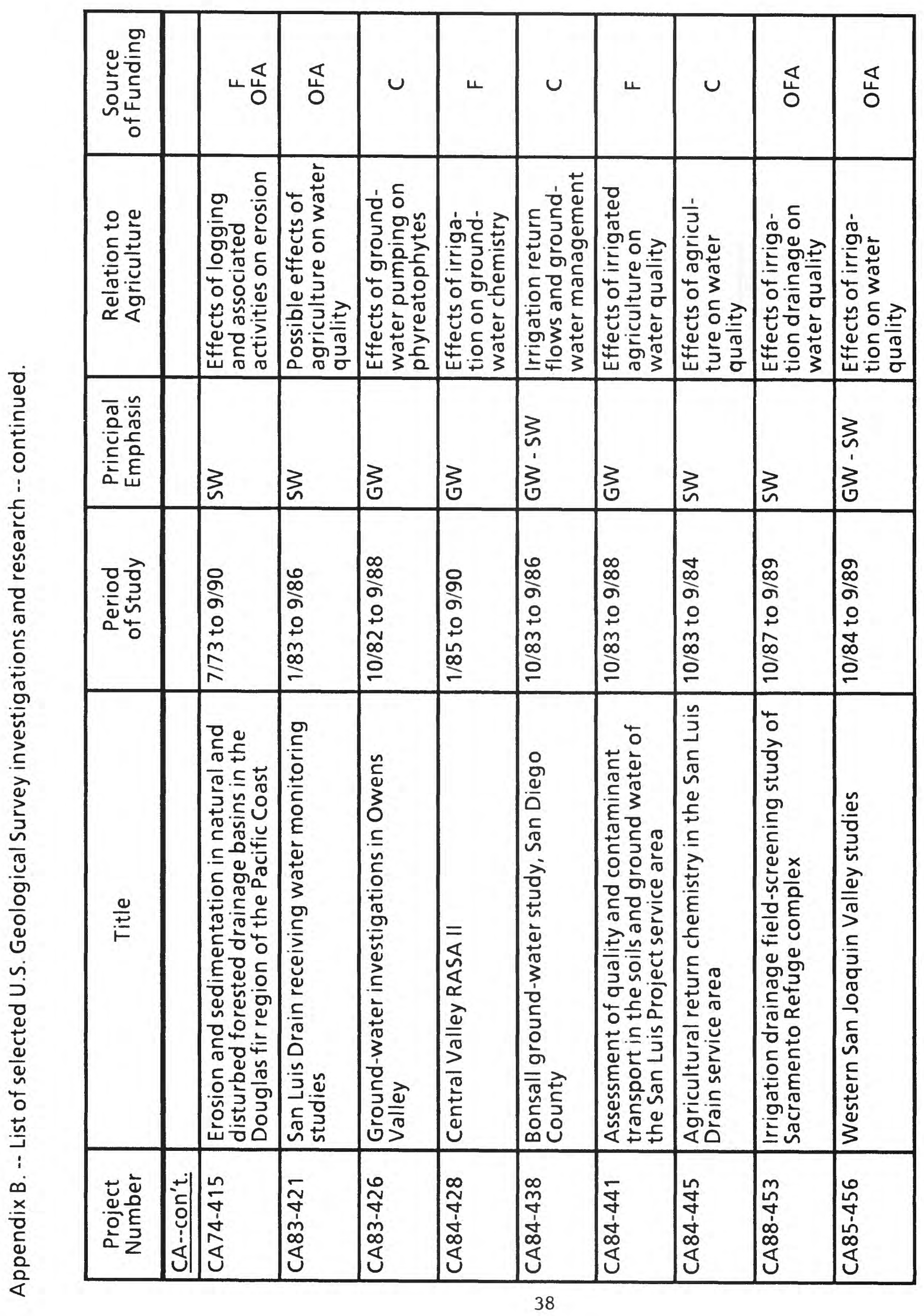




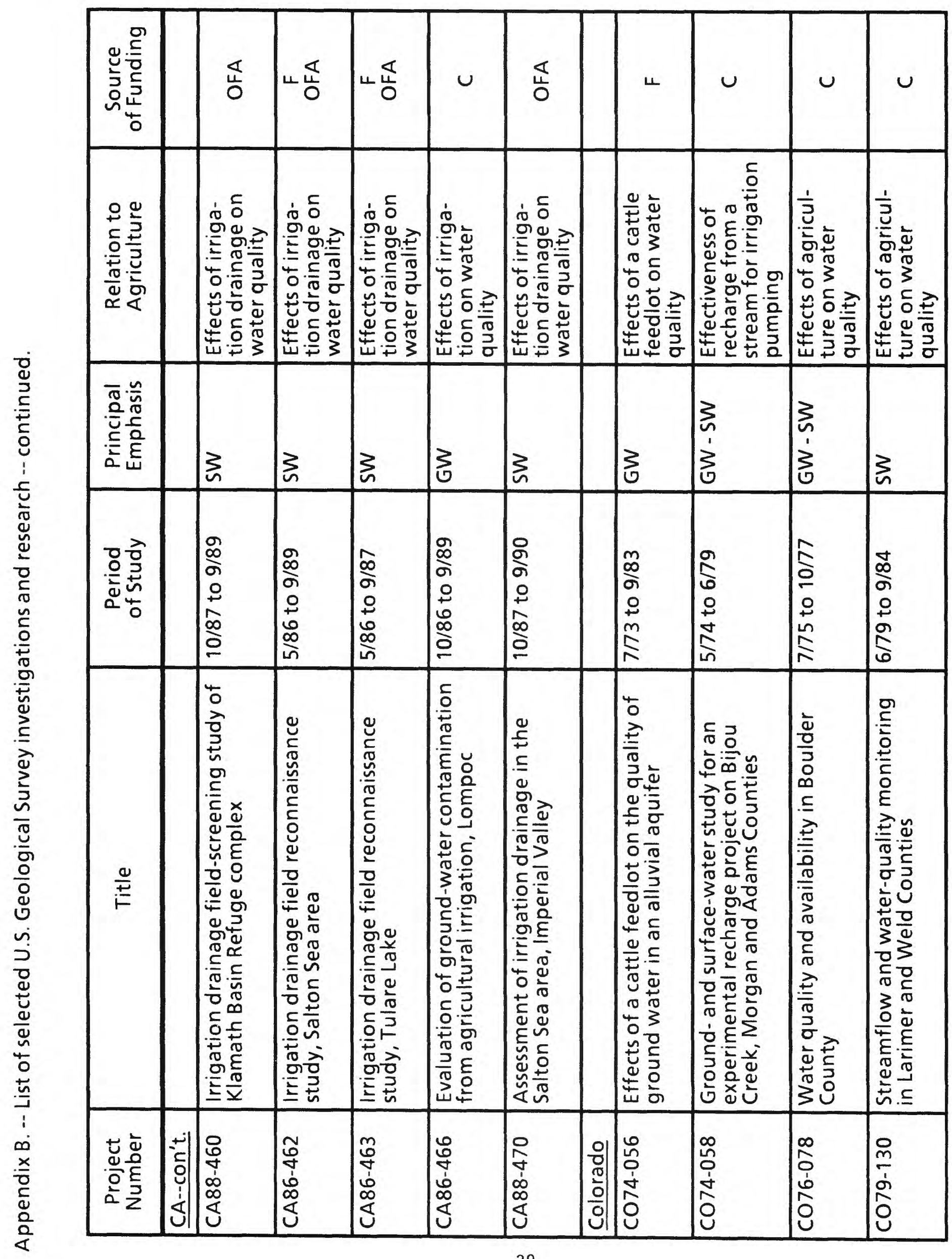




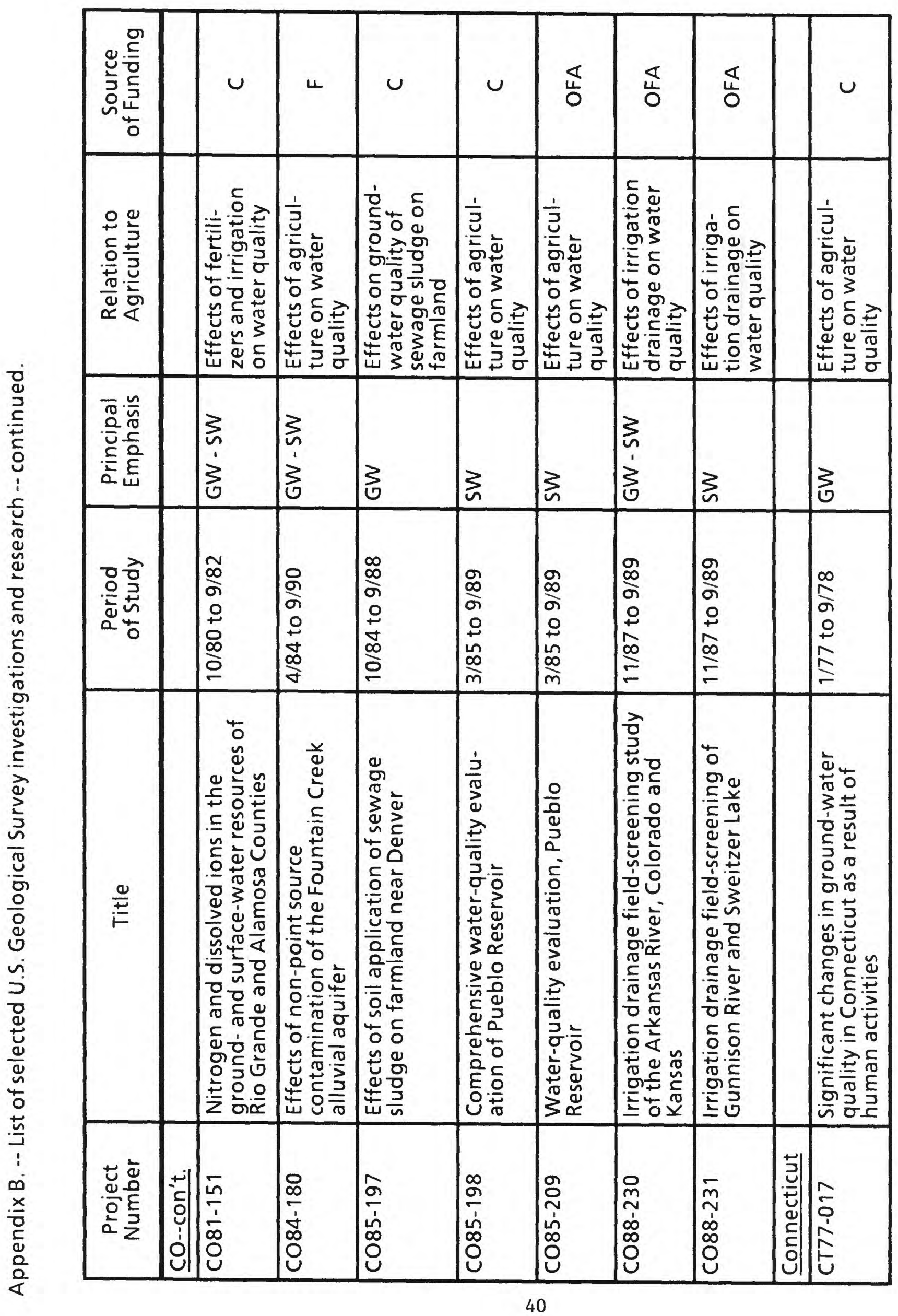




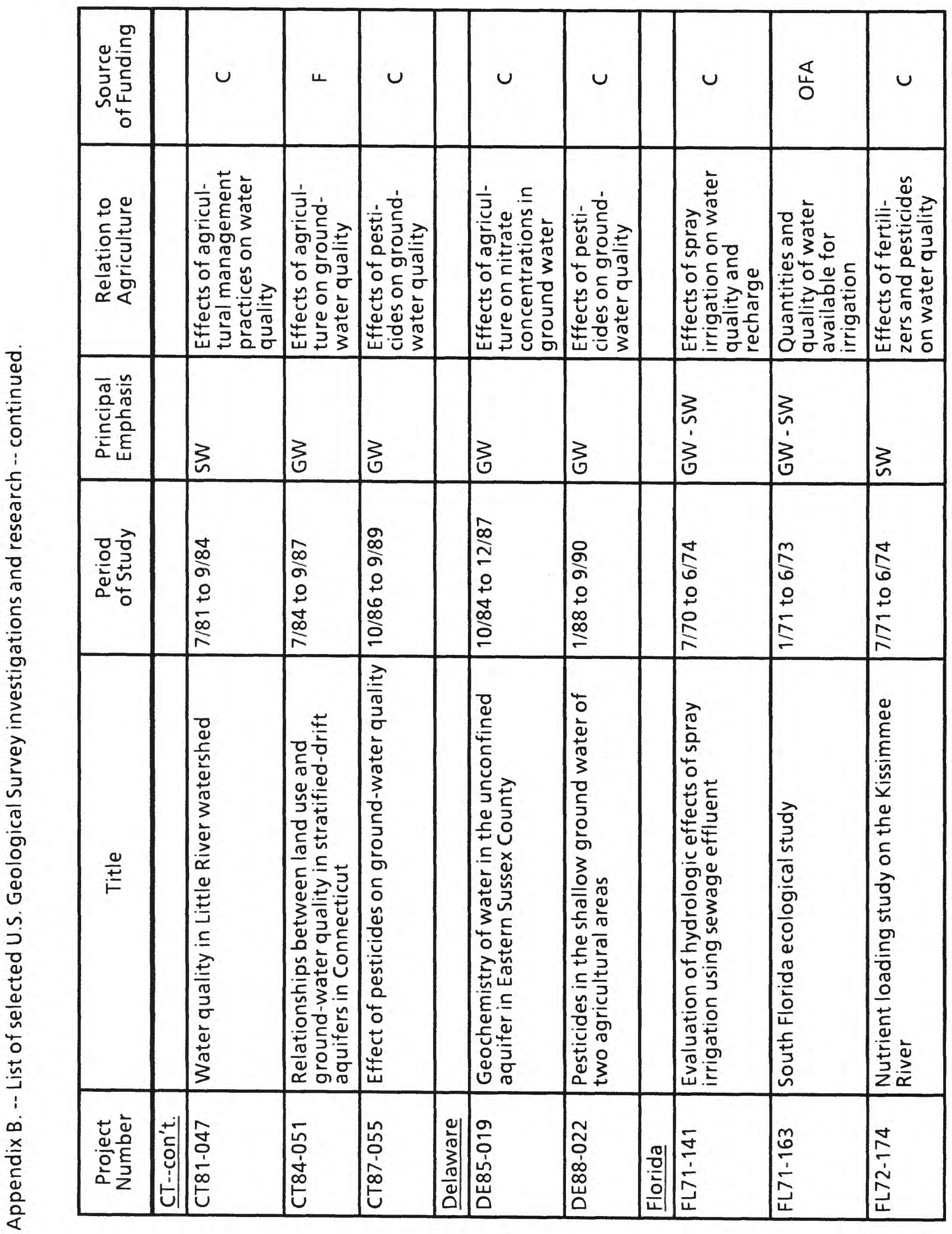




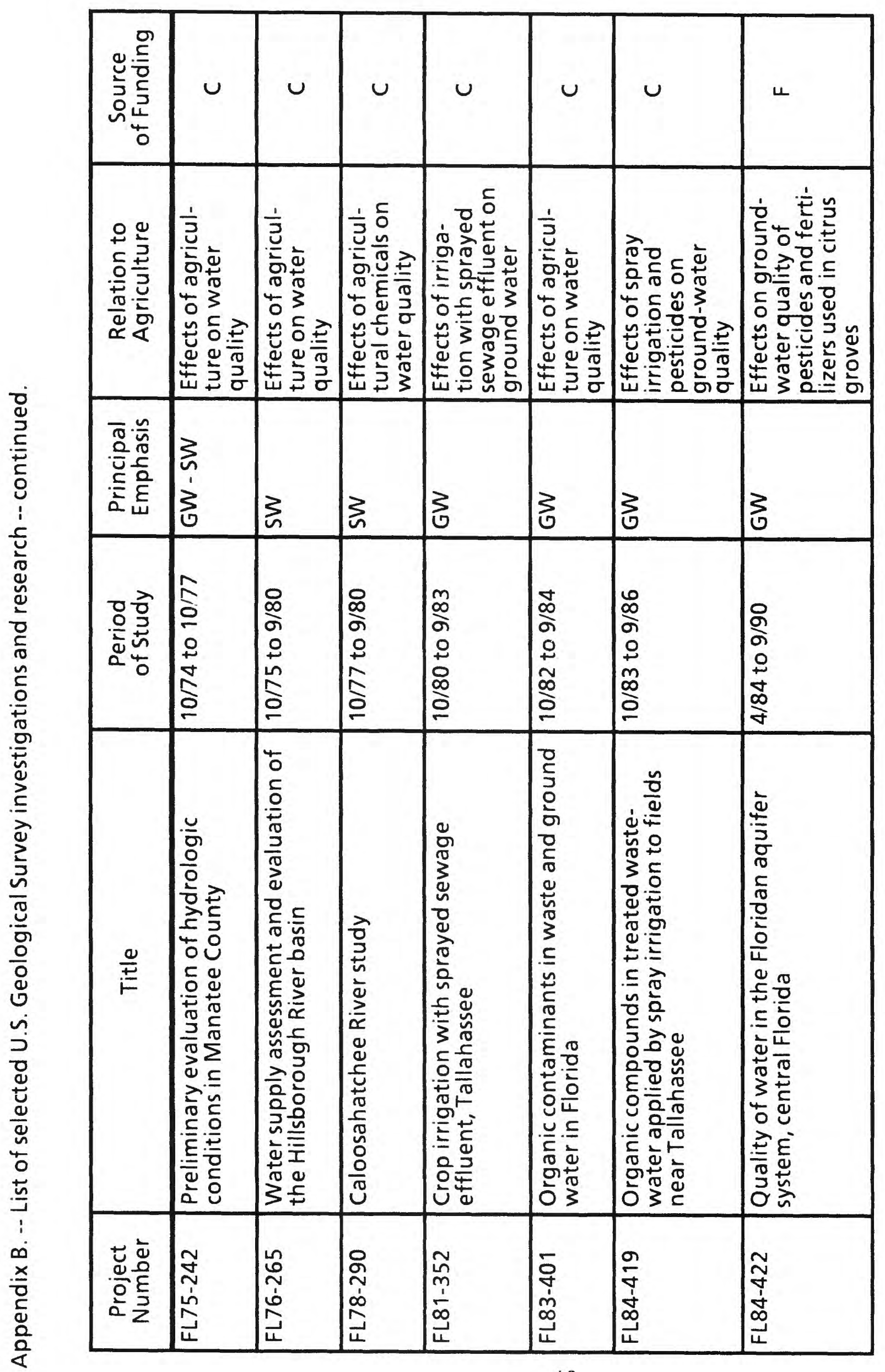




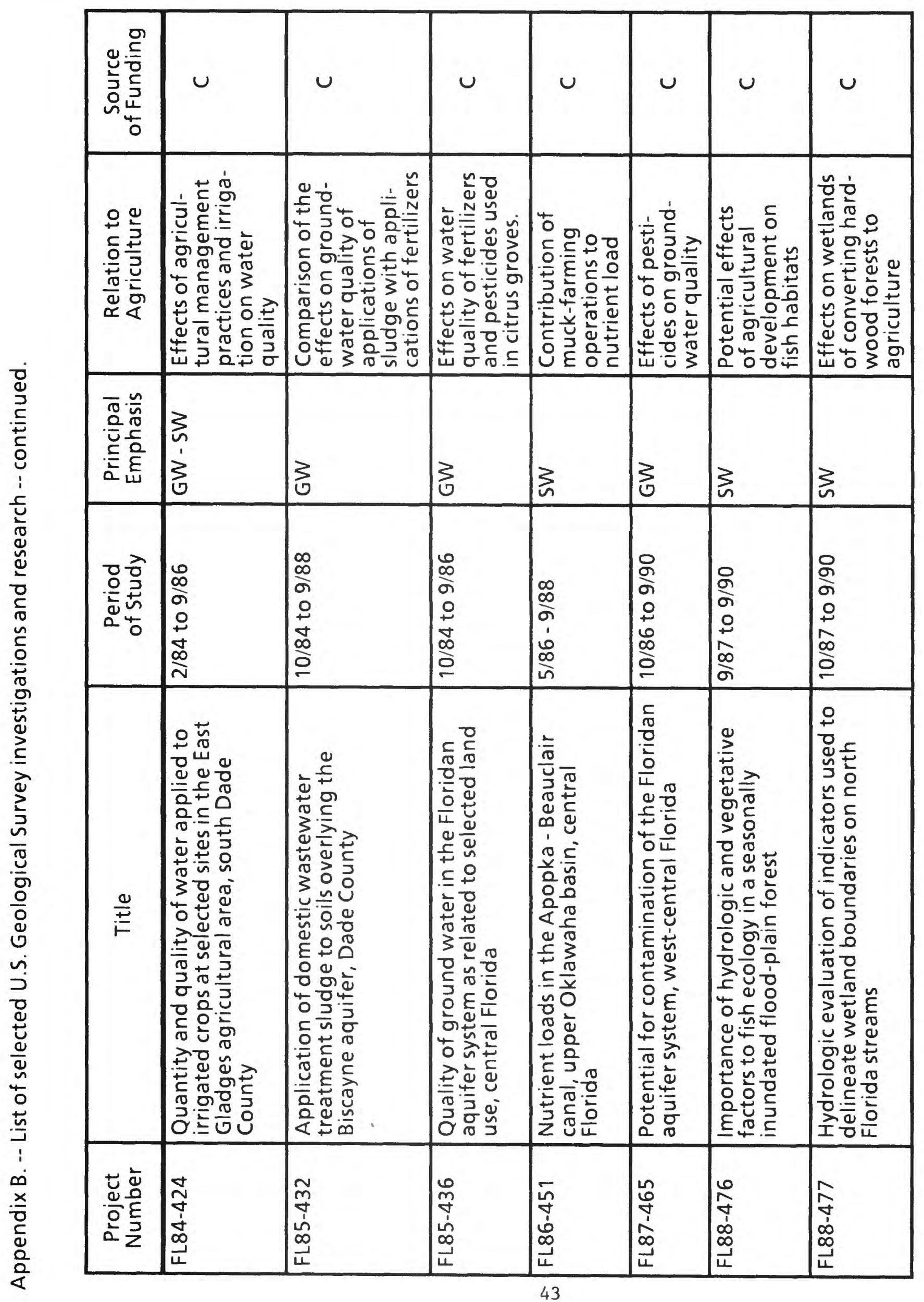




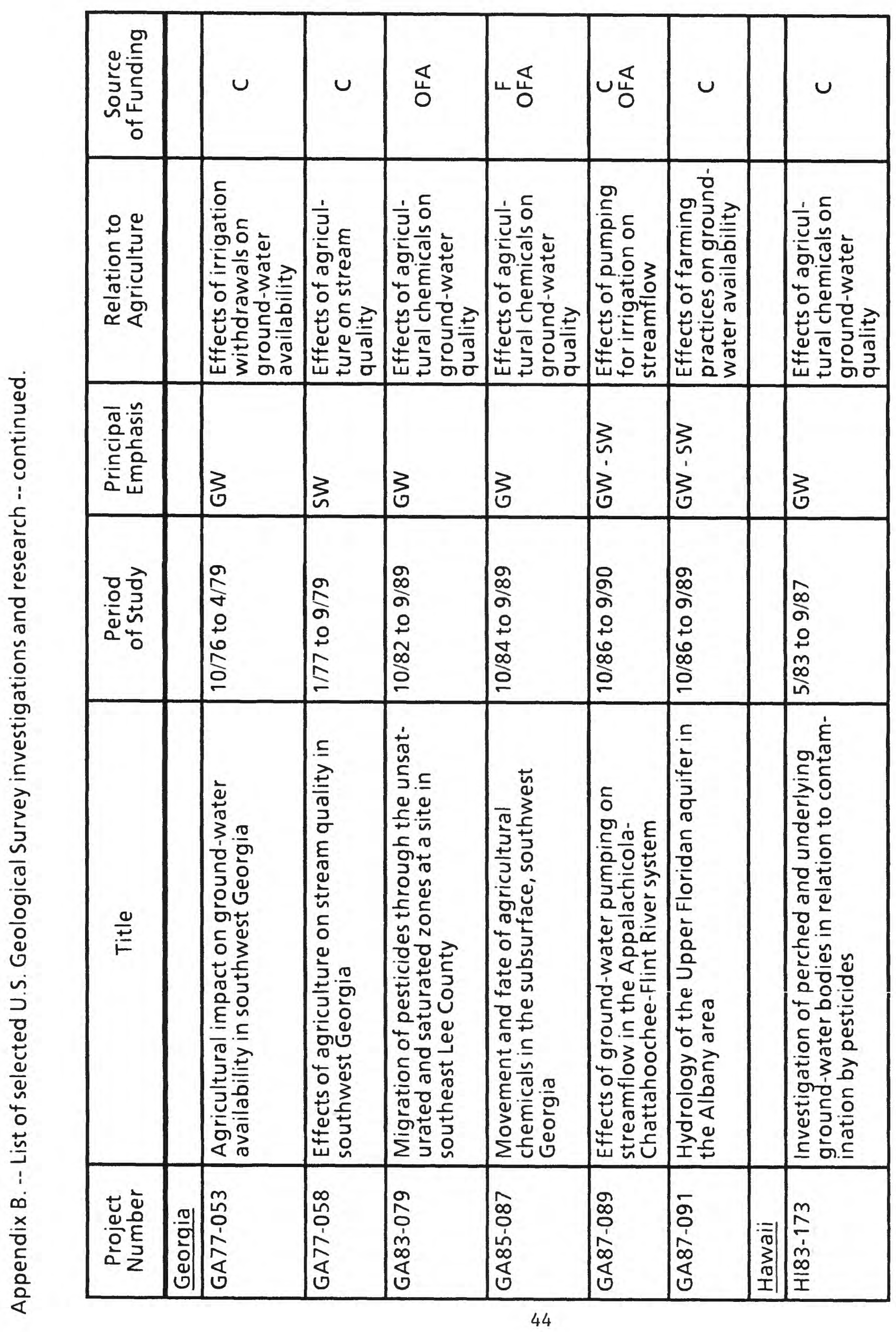




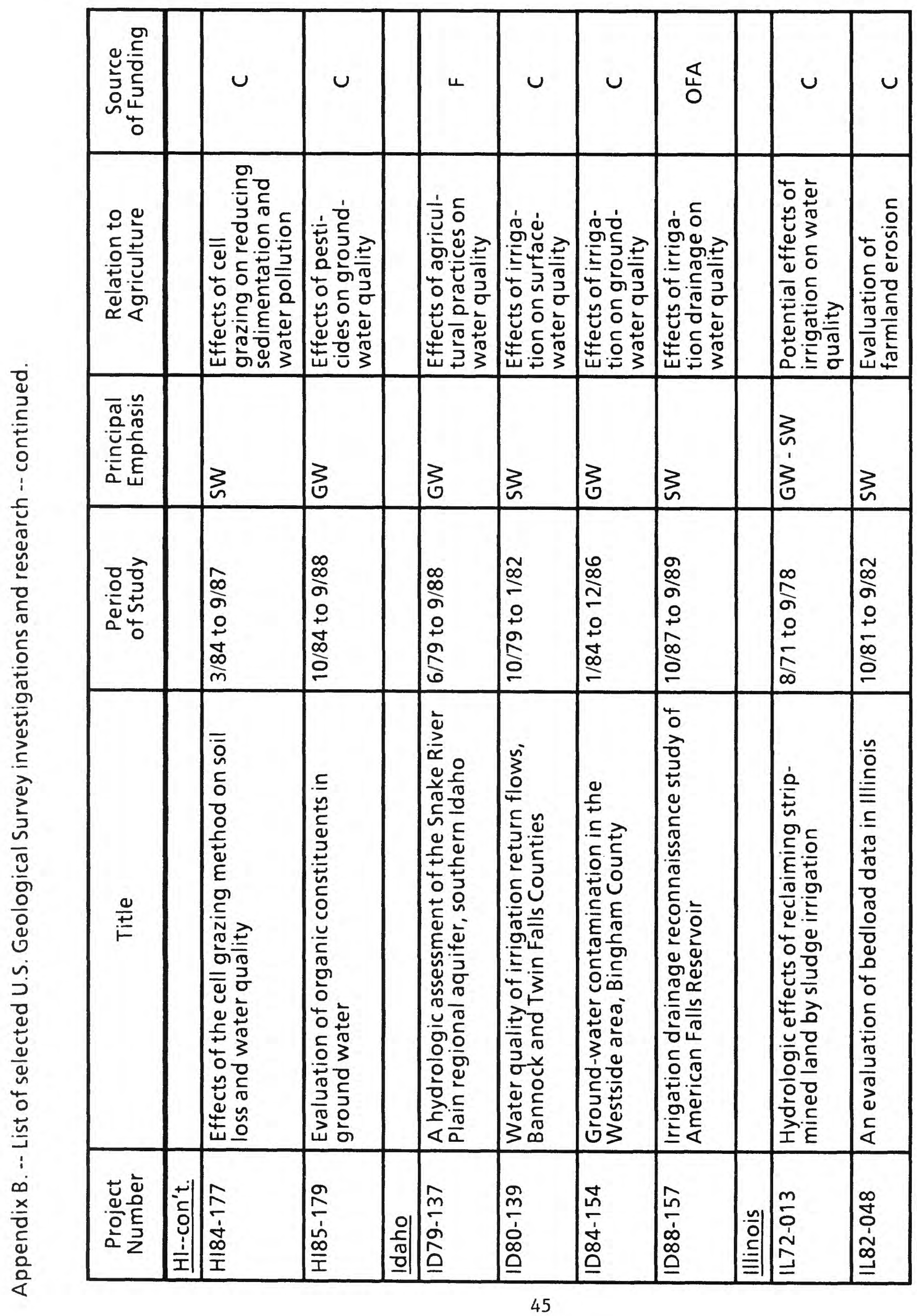




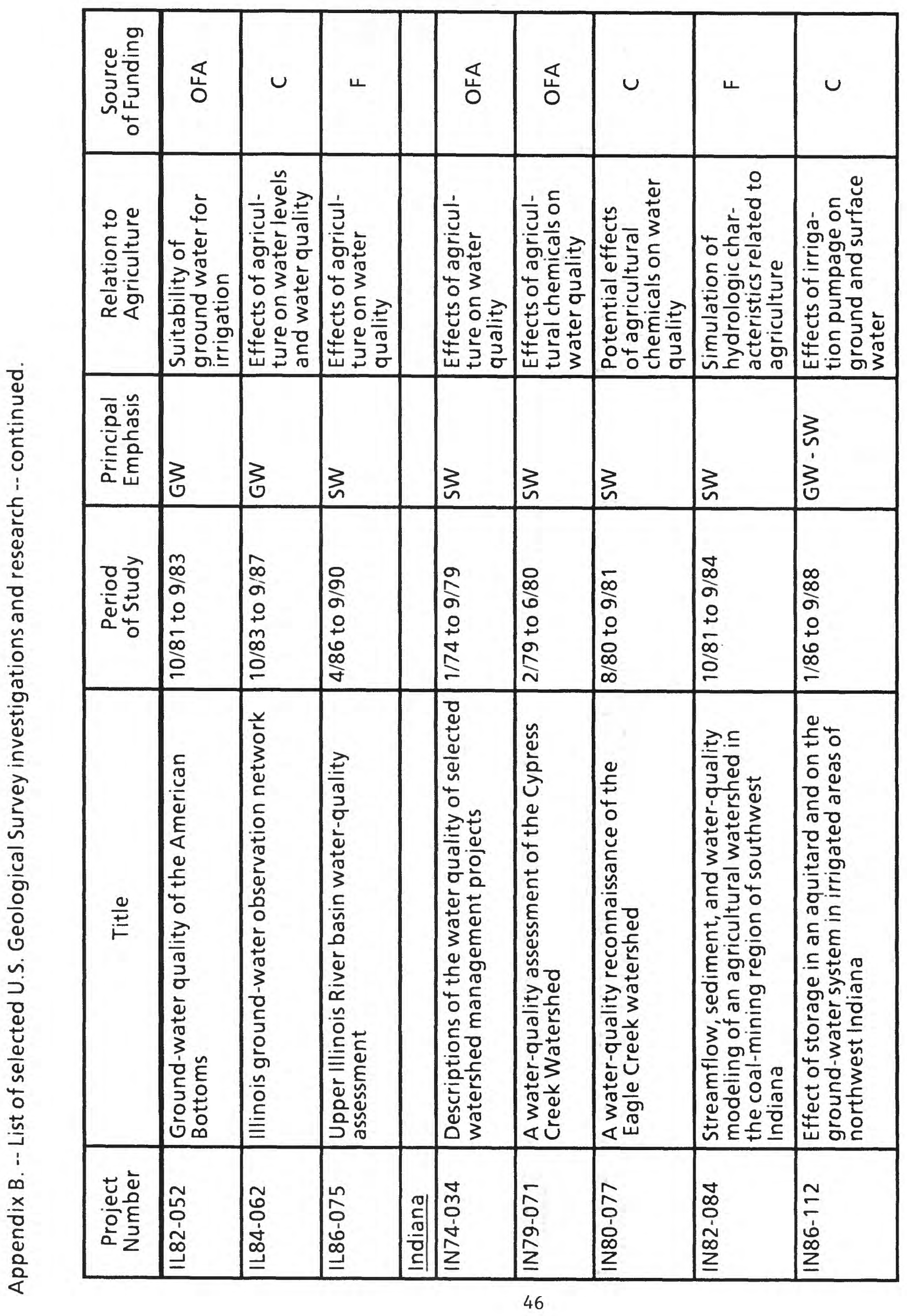




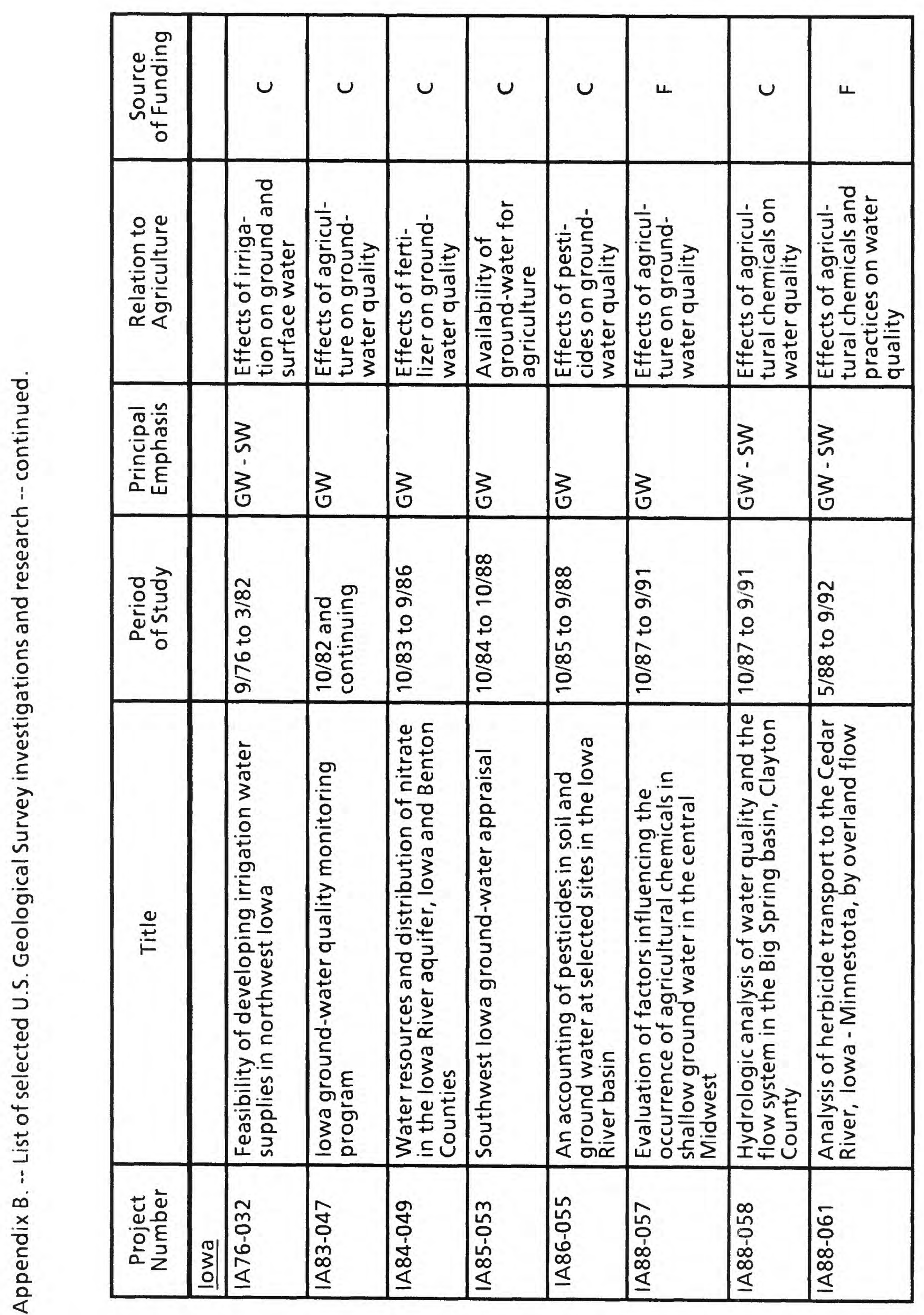




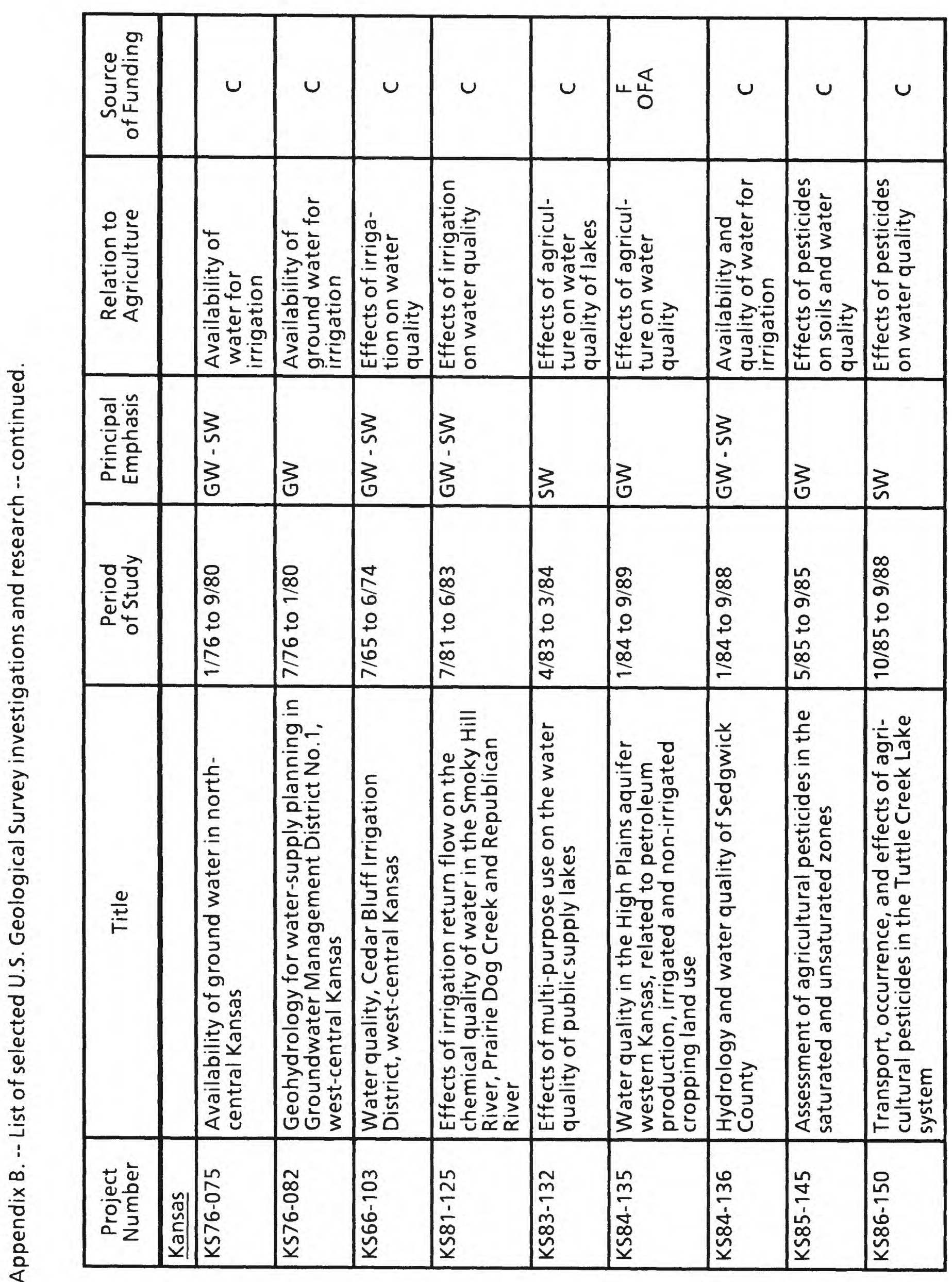




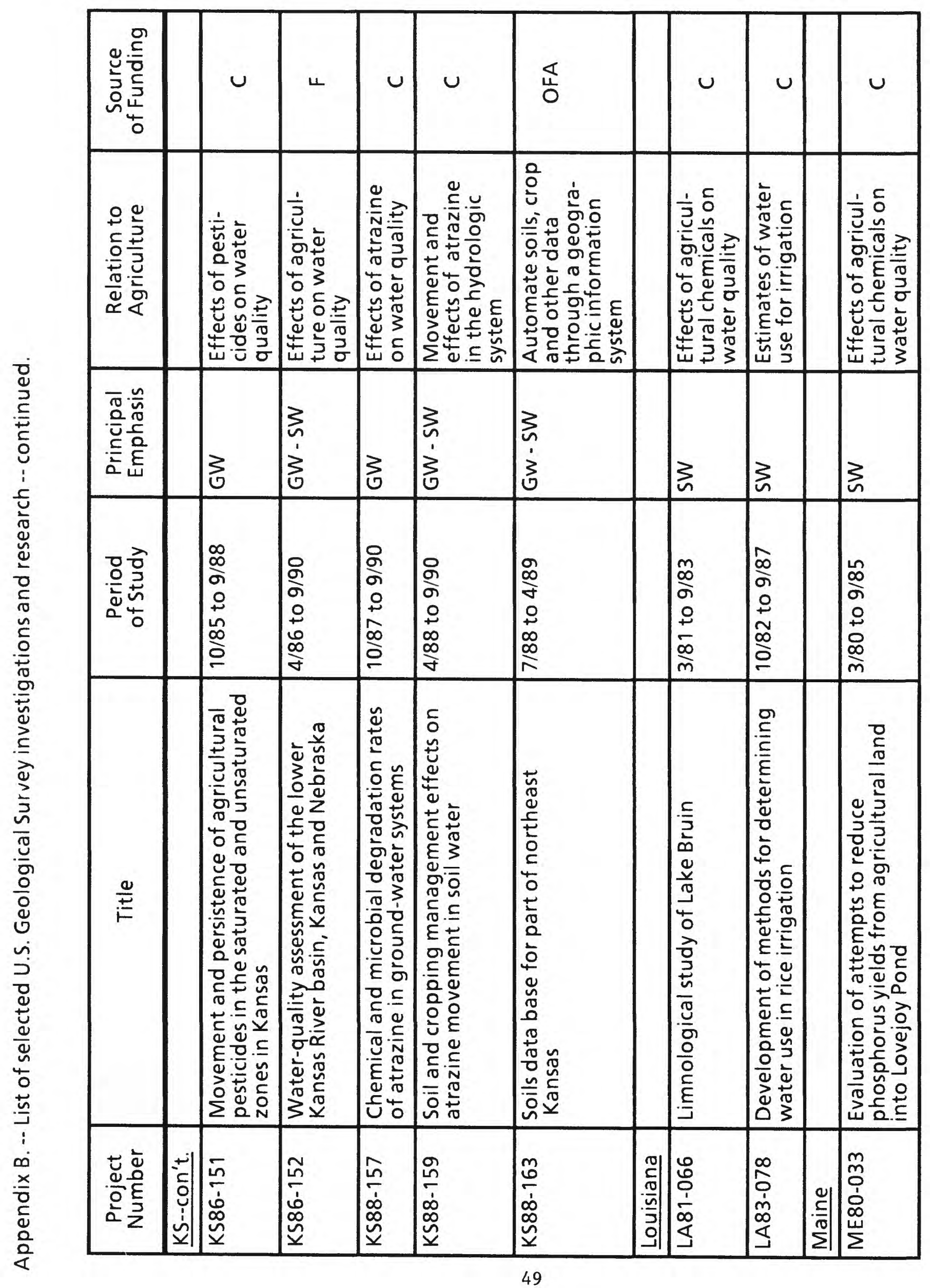




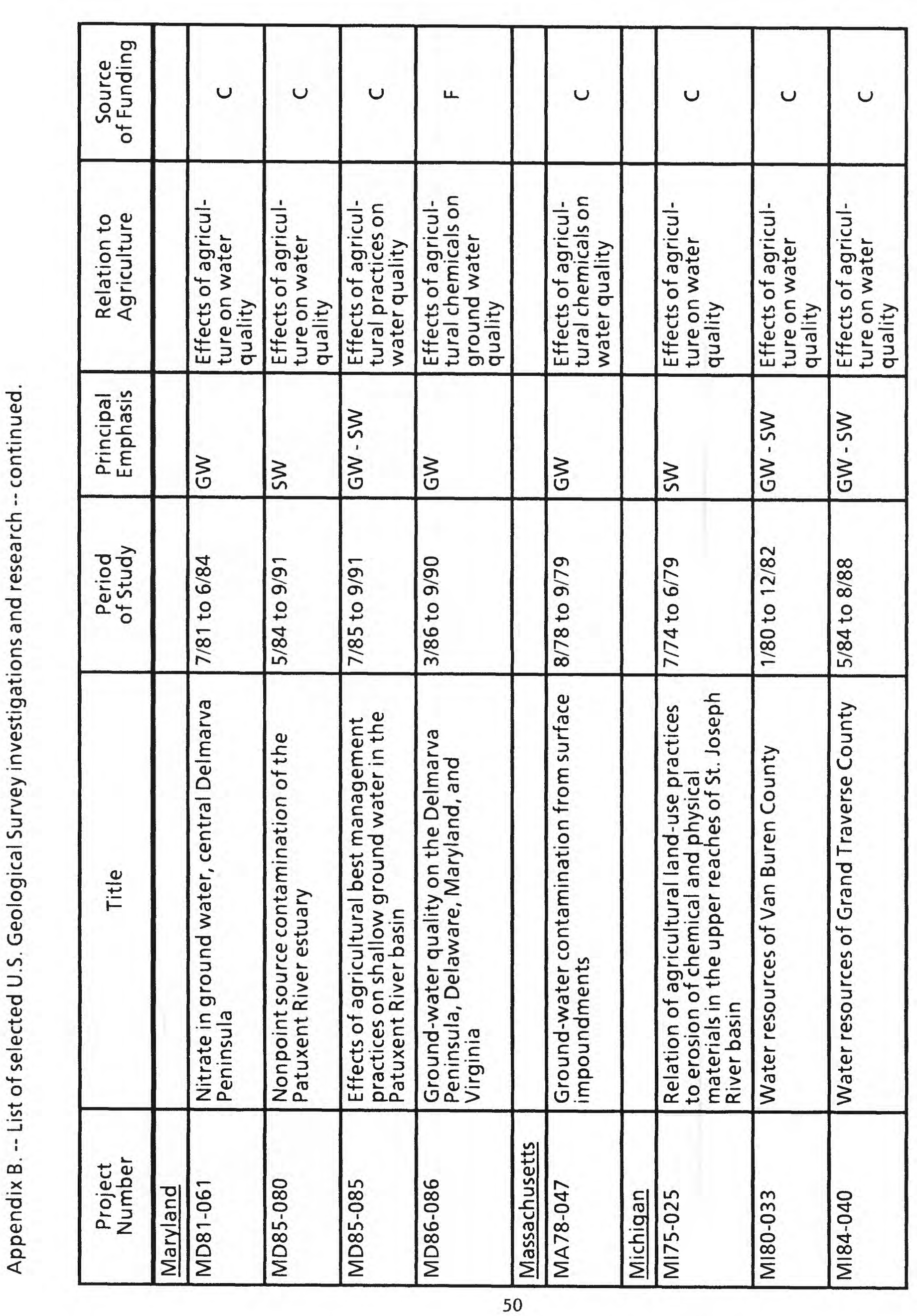




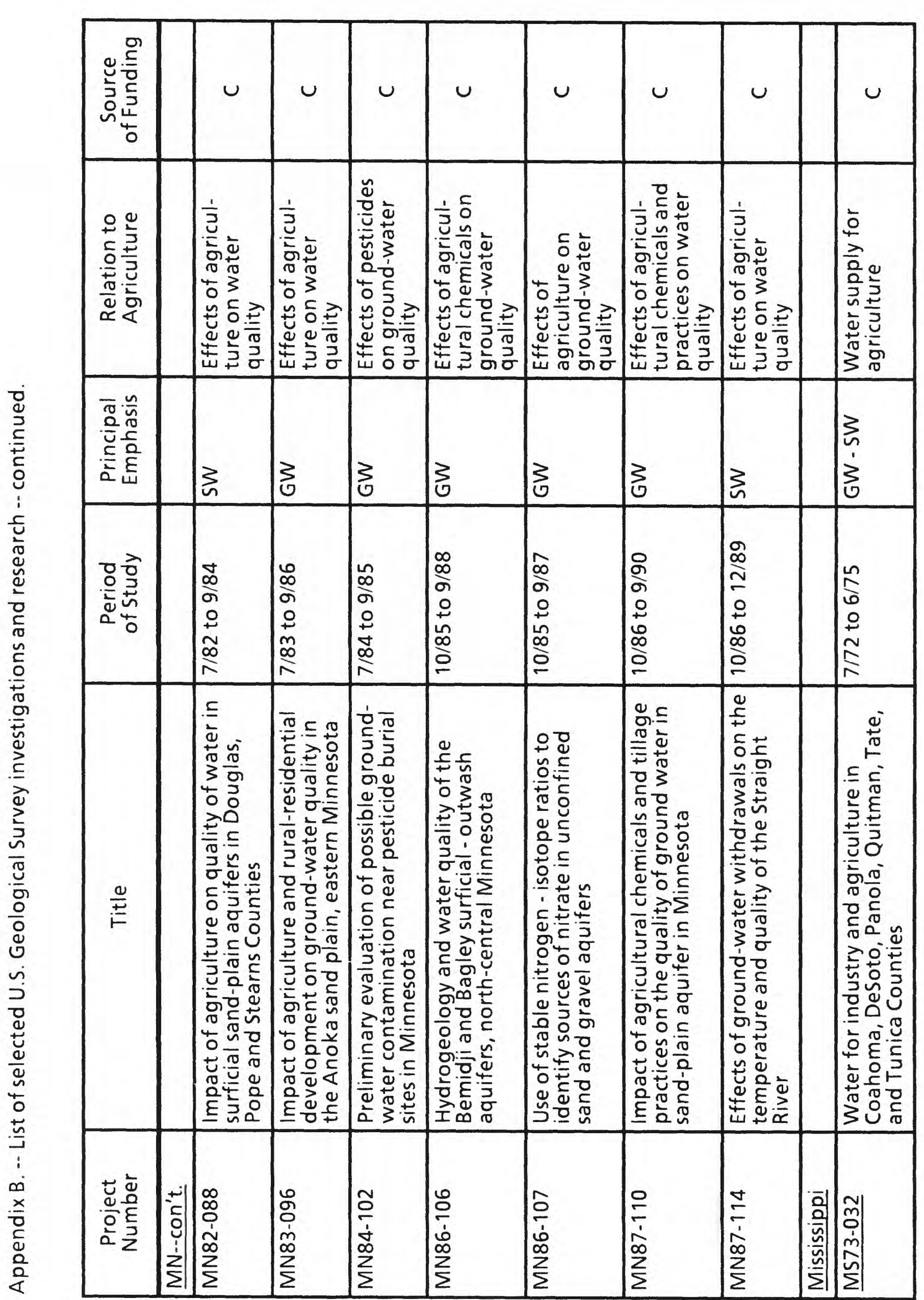




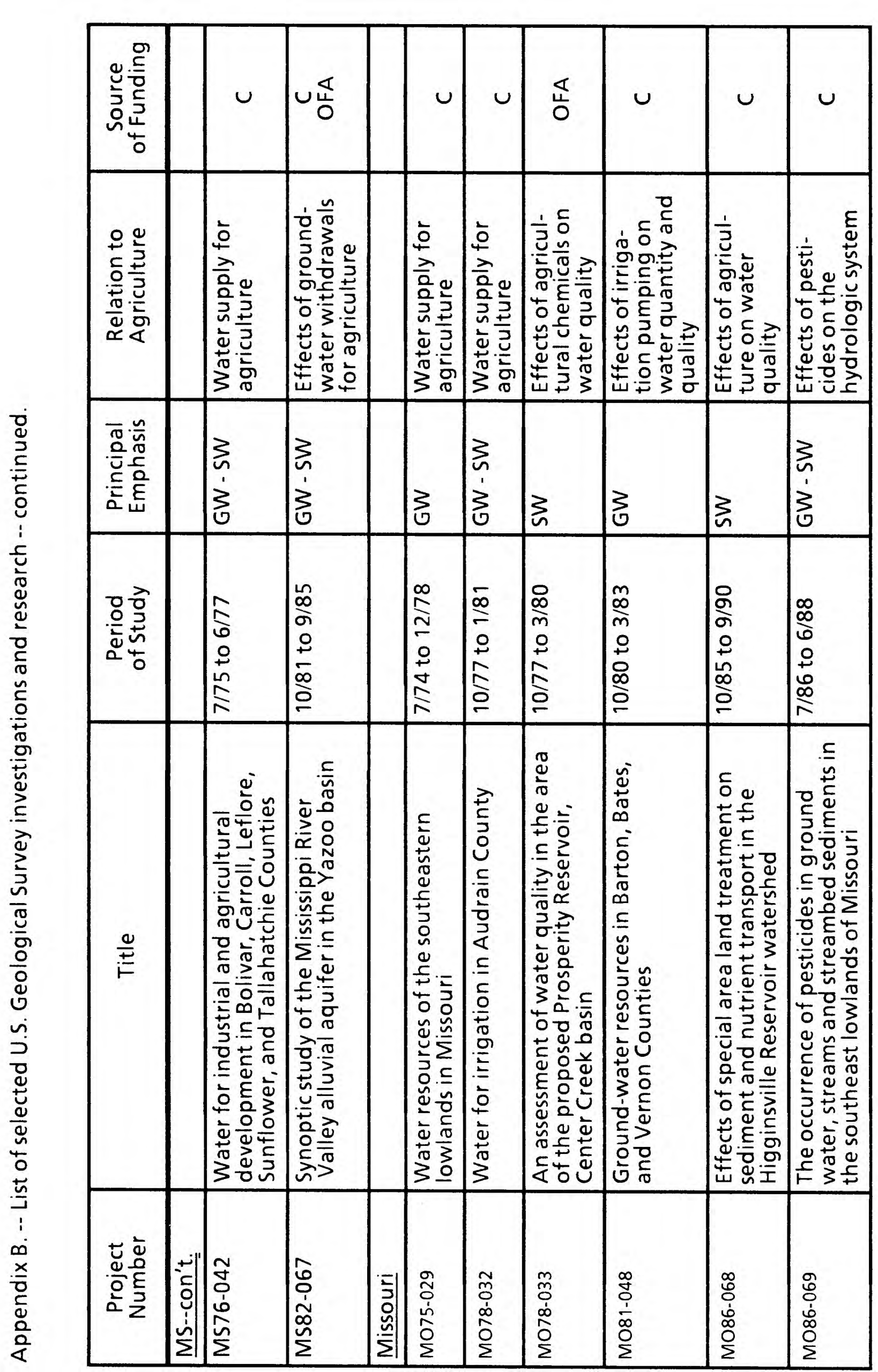




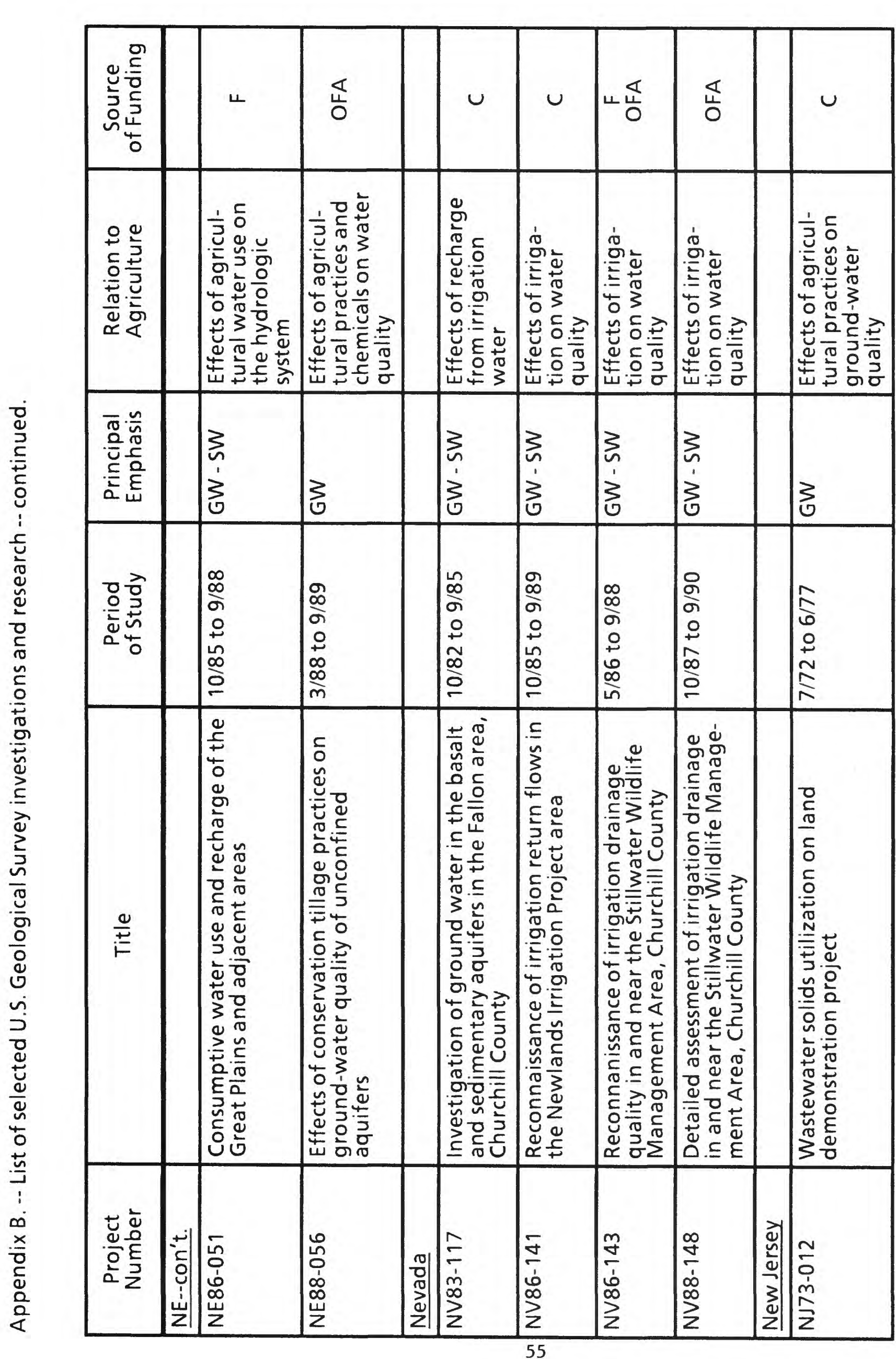




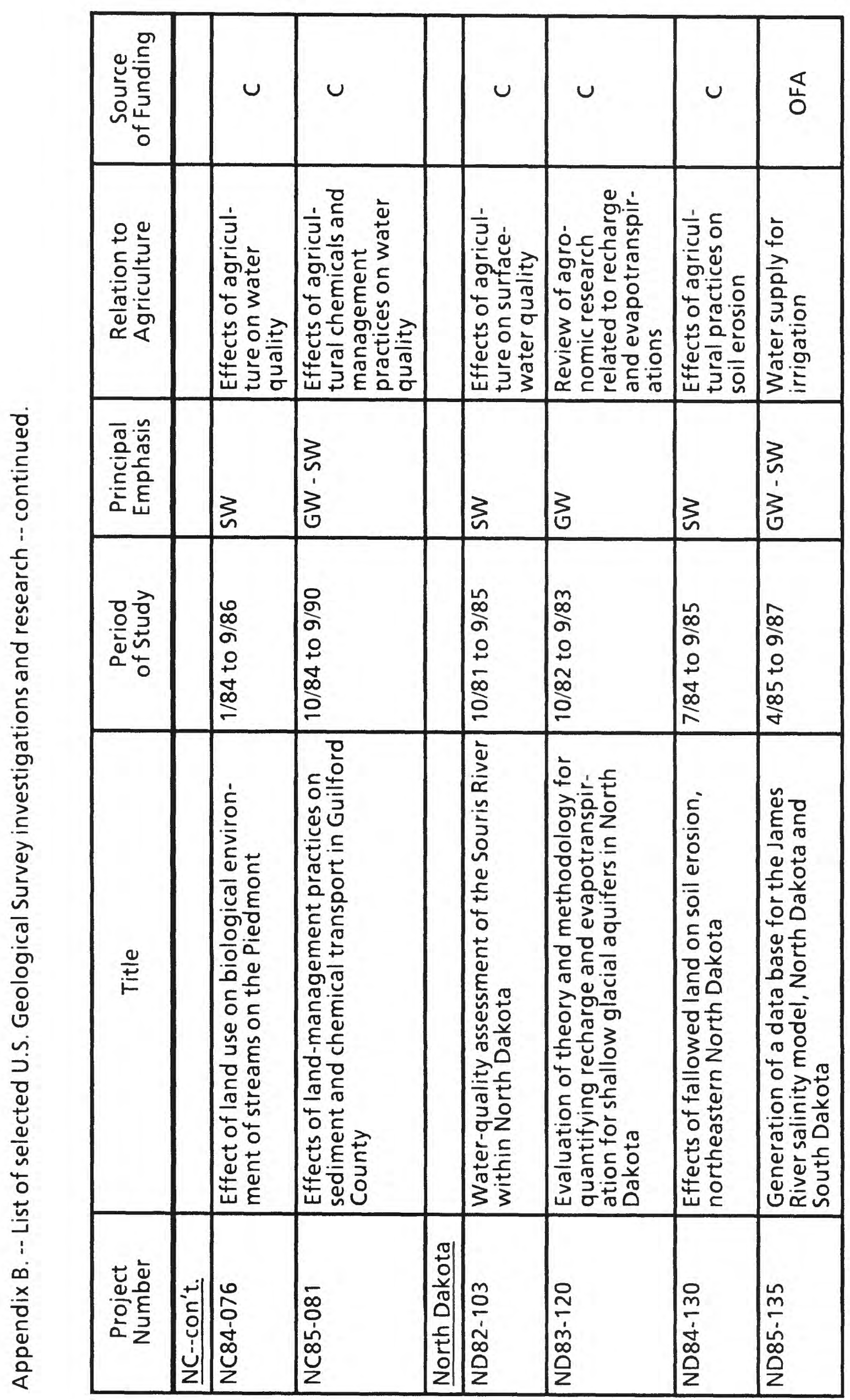




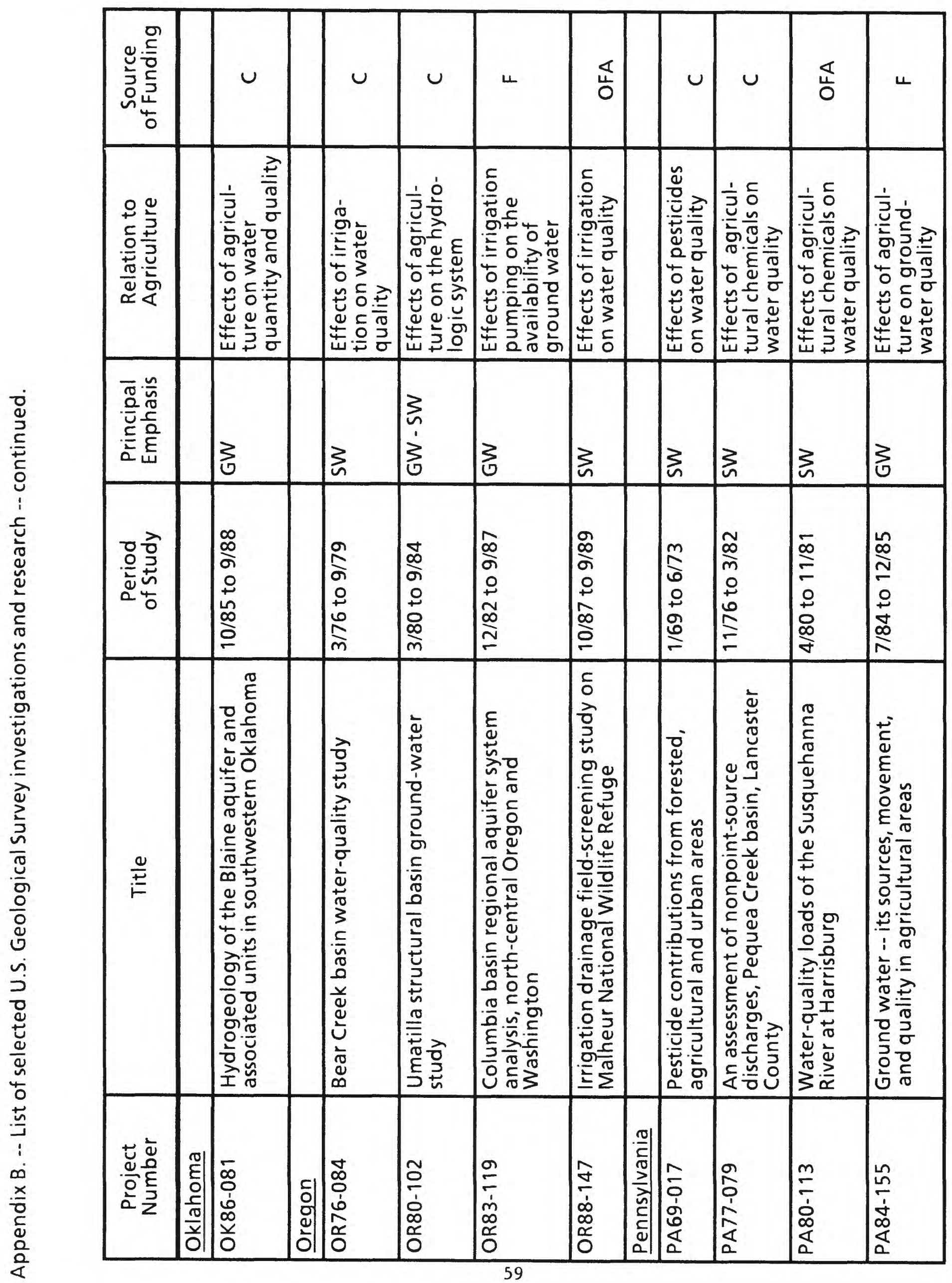




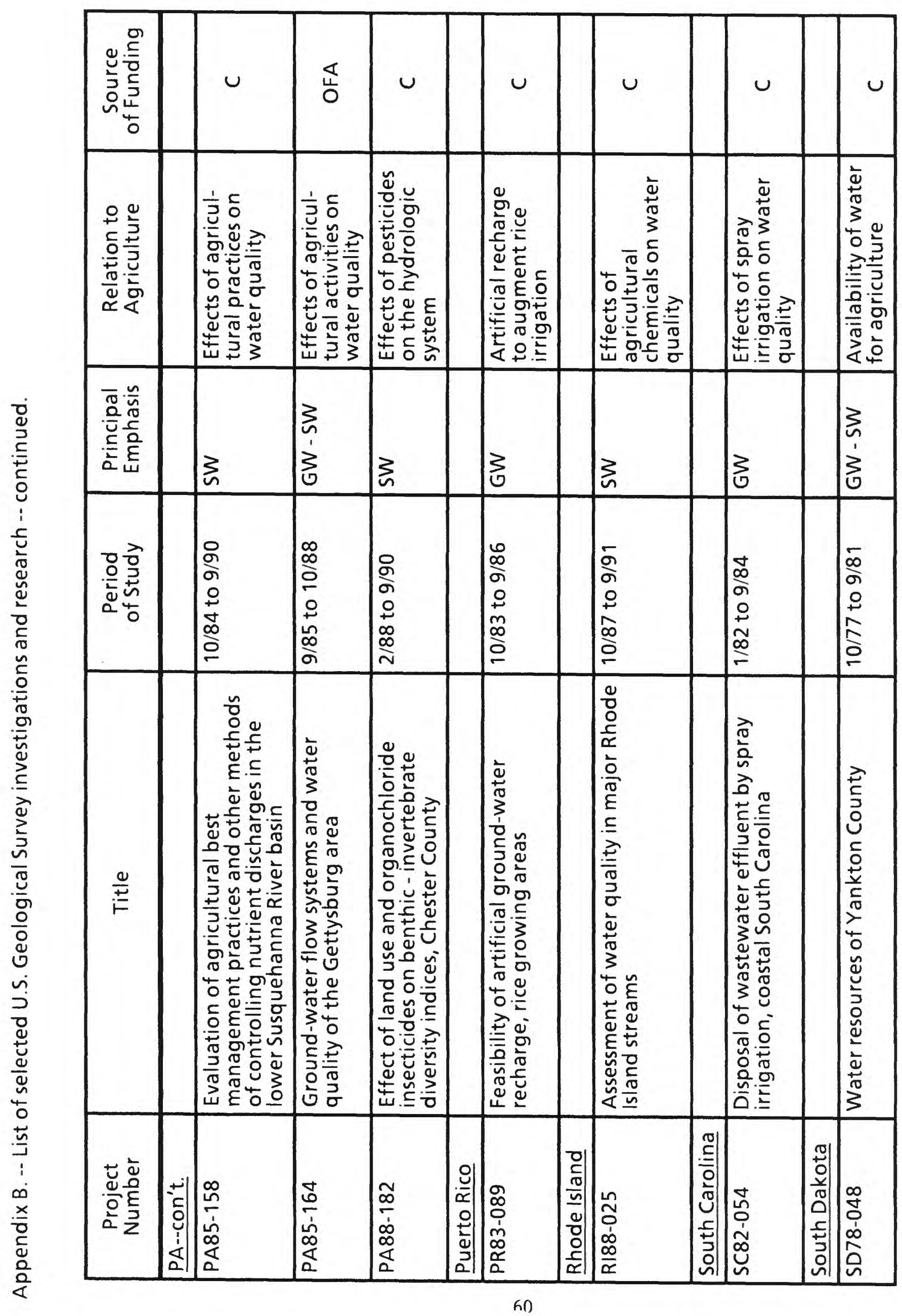




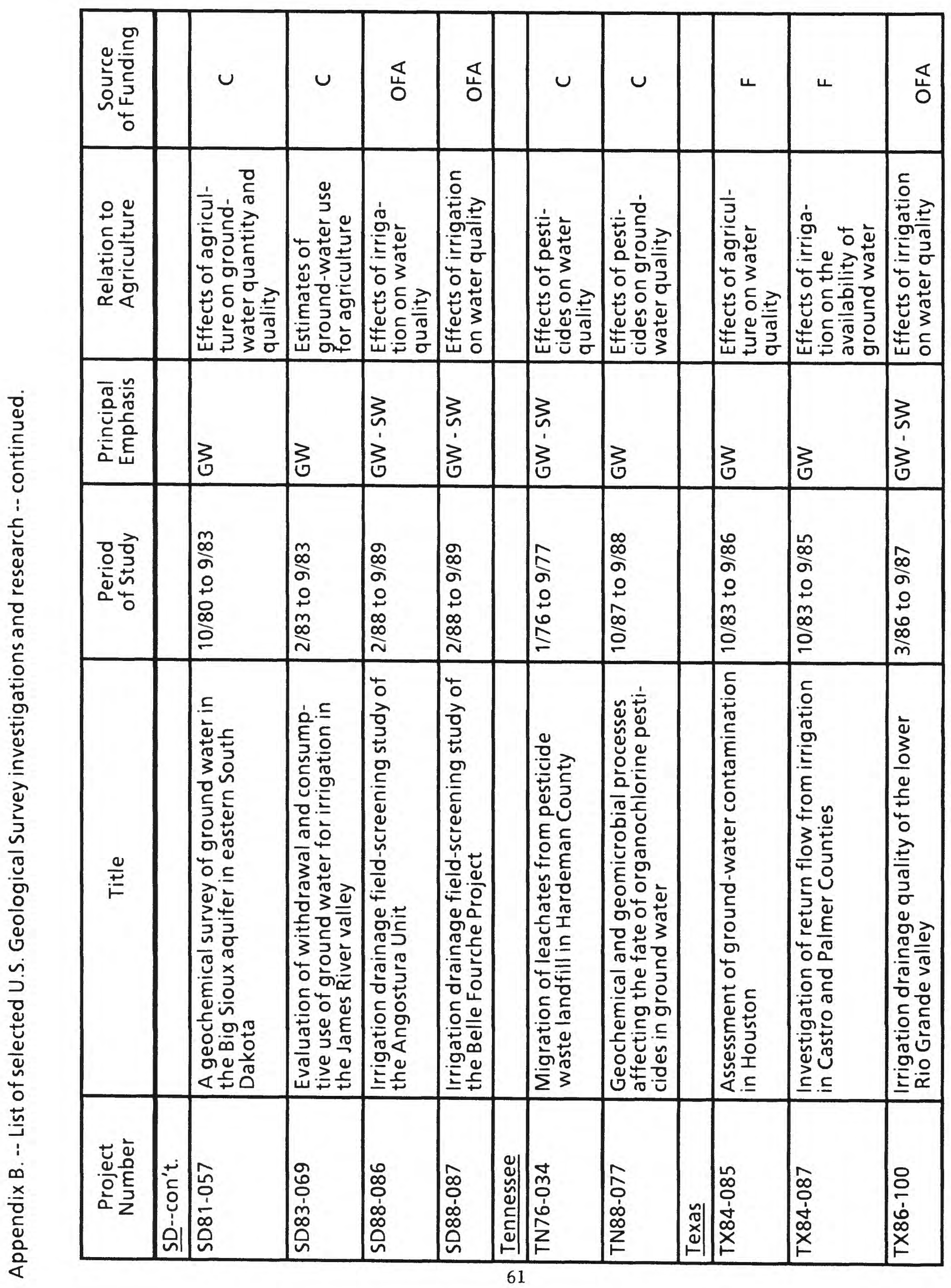




\begin{tabular}{|c|c|c|c|c|c|c|c|c|c|c|c|c|}
\hline 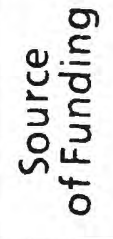 & & $\cup$ & $4 \frac{\varangle}{0}$ & $u$ & $u$ & 壳 & $u$ & & $\frac{\mathbb{4}}{0}$ & & $\cup$ & $\cup$ \\
\hline 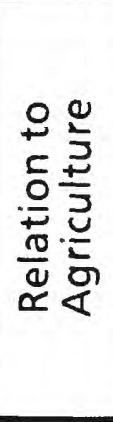 & & 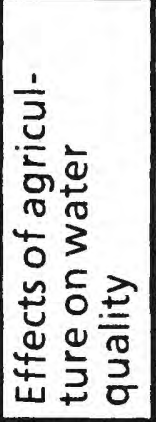 & 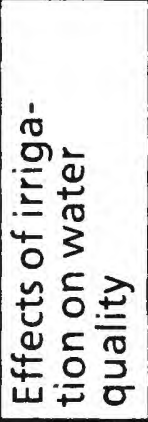 & 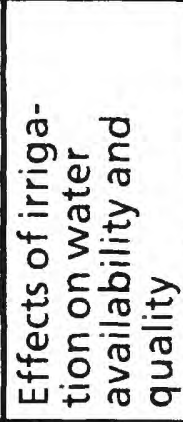 & 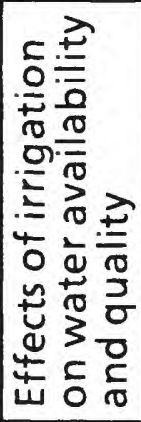 & 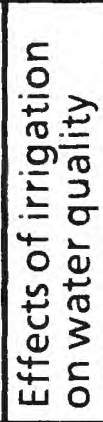 & 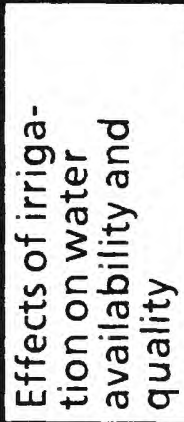 & & 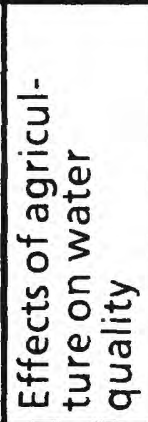 & & 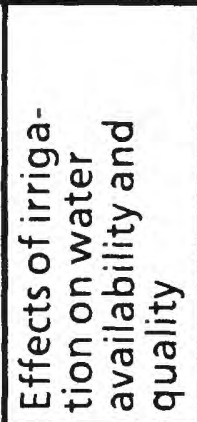 & 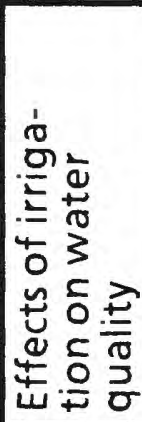 \\
\hline 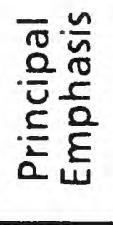 & & $\frac{3}{n}$ & $\sum_{n}$ & $\begin{array}{l}3 \\
\vdots \\
\vdots \\
0\end{array}$ & $\frac{3}{4}$ & $\sum_{3}^{3}$ & $\frac{3}{4}$ & & $\sum_{n}$ & & $\sum_{3}^{3}$ & $\sum_{0}^{3}$ \\
\hline 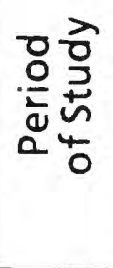 & & $\begin{array}{l}\frac{5}{\infty} \\
0 \\
0 \\
+ \\
0 \\
\frac{1}{N}\end{array}$ & $\begin{array}{l}\infty \\
\infty \\
0 \\
0 \\
+ \\
\infty \\
\infty \\
0\end{array}$ & $\begin{array}{l}\text { o } \\
0 \\
0 \\
+ \\
0 \\
0 \\
0\end{array}$ & $\begin{array}{l}8 \\
\frac{9}{6} \\
0 \\
+ \\
\infty \\
\infty \\
m\end{array}$ & $\begin{array}{l}8 \\
\text { o } \\
\text { ô } \\
0 \\
+ \\
\infty \\
\infty \\
0\end{array}$ & $\begin{array}{l}0 \\
\text { o } \\
6 \\
0 \\
+ \\
\infty \\
\infty \\
\end{array}$ & & 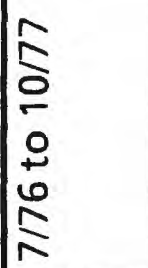 & & $\begin{array}{l}0 \\
0 \\
\sigma \\
0 \\
0 \\
0 \\
\frac{1}{8}\end{array}$ & $\begin{array}{l}n \\
\frac{1}{0} \\
0 \\
+ \\
m \\
\frac{1}{0} \\
0\end{array}$ \\
\hline$\frac{Q}{E}$ & & 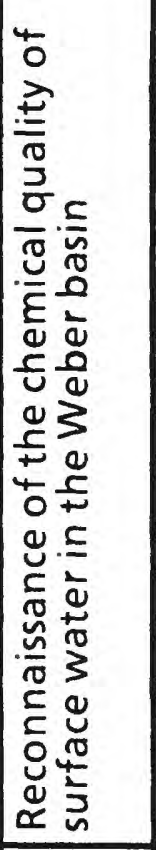 & 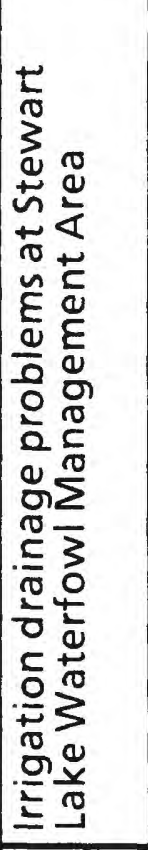 & 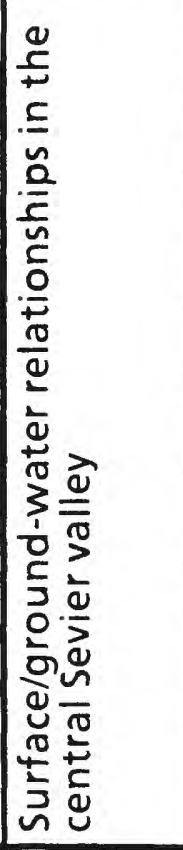 & 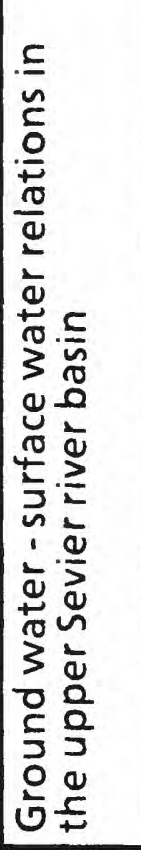 & 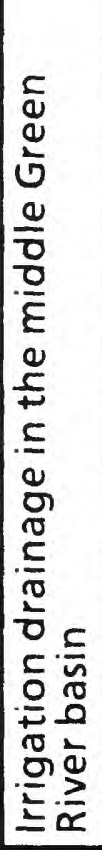 & 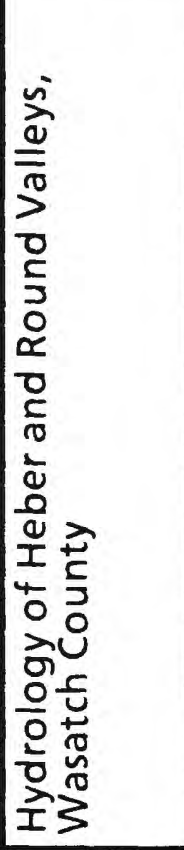 & & 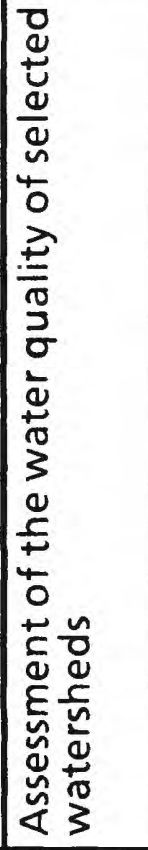 & & 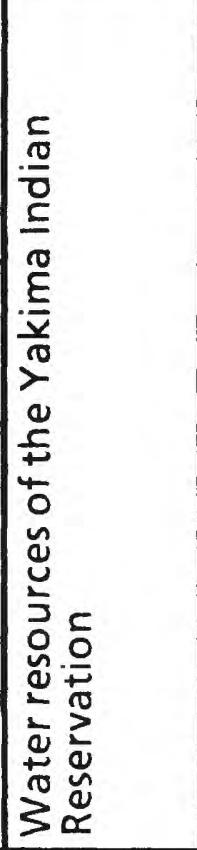 & 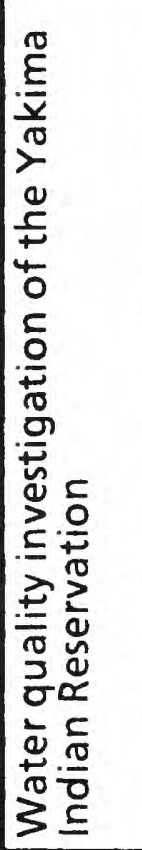 \\
\hline 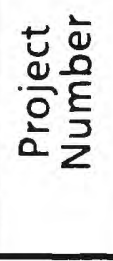 & $\mid \begin{array}{c}\frac{5}{5} \\
\pm \\
5\end{array}$ & $\begin{array}{l}\frac{j}{\sigma} \\
\frac{1}{5} \\
\frac{5}{5}\end{array}$ & $\begin{array}{l}\frac{9}{1} \\
\frac{1}{1} \\
\infty \\
5 \\
5\end{array}$ & $\begin{array}{l}0 \\
\infty \\
\frac{1}{1} \\
\infty \\
5 \\
5\end{array}$ & $\begin{array}{l}8 \\
\frac{9}{1} \\
\infty \\
\infty \\
5 \\
5\end{array}$ & $\begin{array}{l}5 \\
\sigma \\
\infty \\
\infty \\
5 \\
5\end{array}$ & $\begin{array}{l}\frac{J}{\sigma} \\
\frac{1}{\infty} \\
\infty \\
5 \\
5\end{array}$ & $\begin{array}{l}. ㅎ \\
\text { 의 } \\
\frac{0}{>}\end{array}$ & 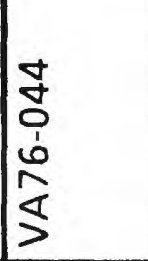 & 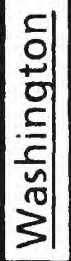 & $\begin{array}{l}\frac{9}{8} \\
0 \\
\frac{1}{3} \\
3\end{array}$ & $\frac{m}{\frac{m}{5}} \frac{5}{5}$ \\
\hline
\end{tabular}




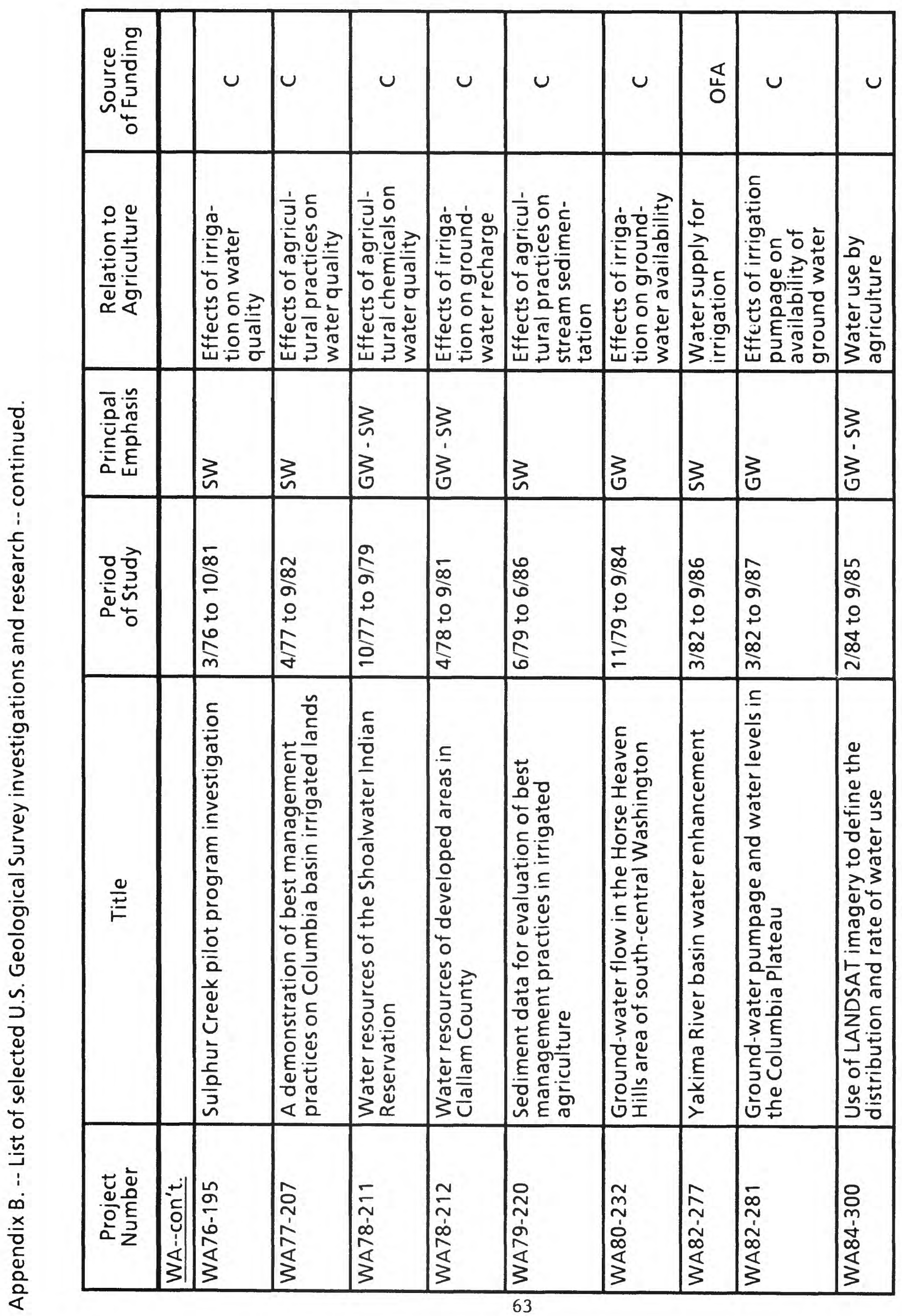




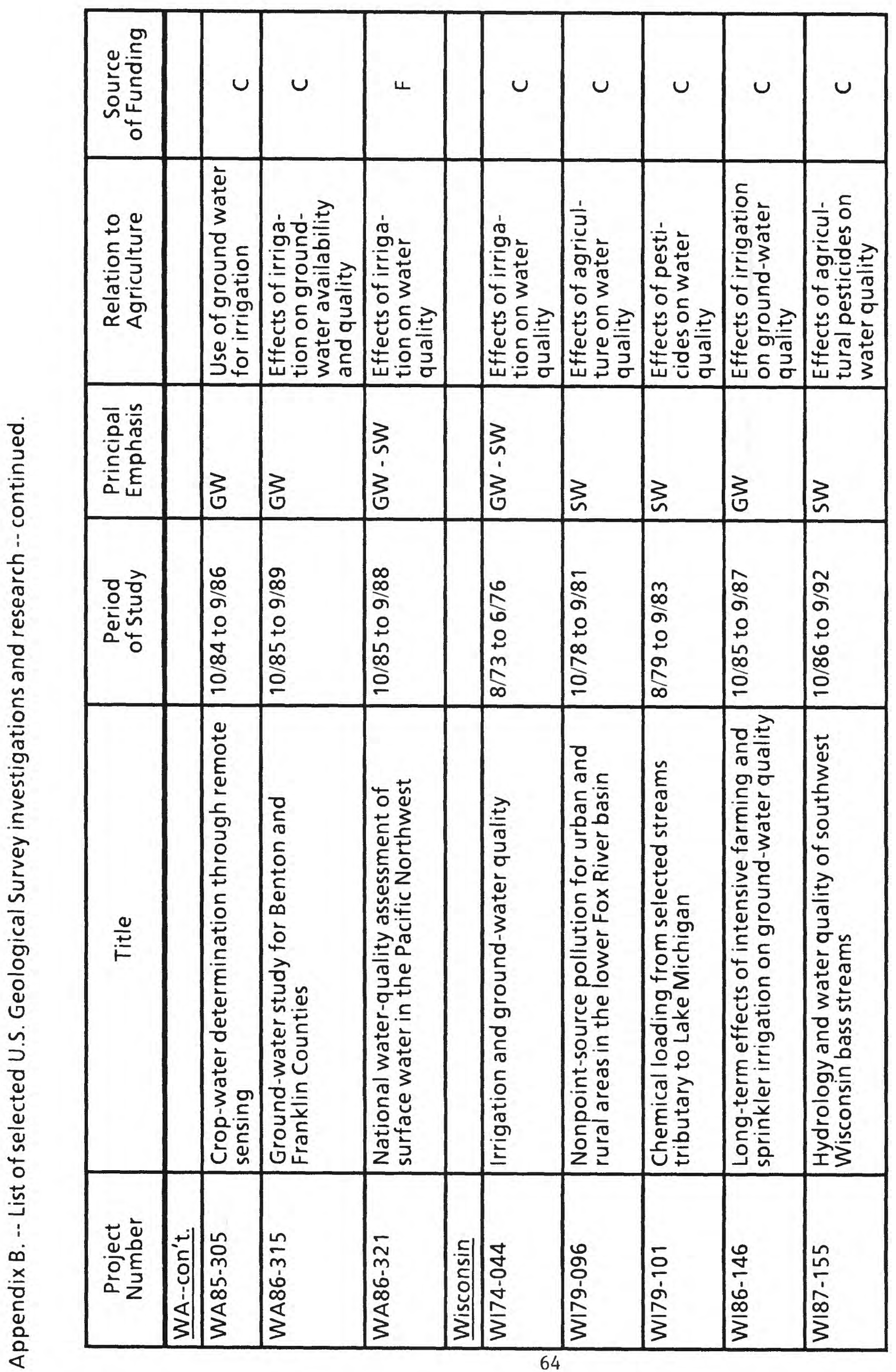




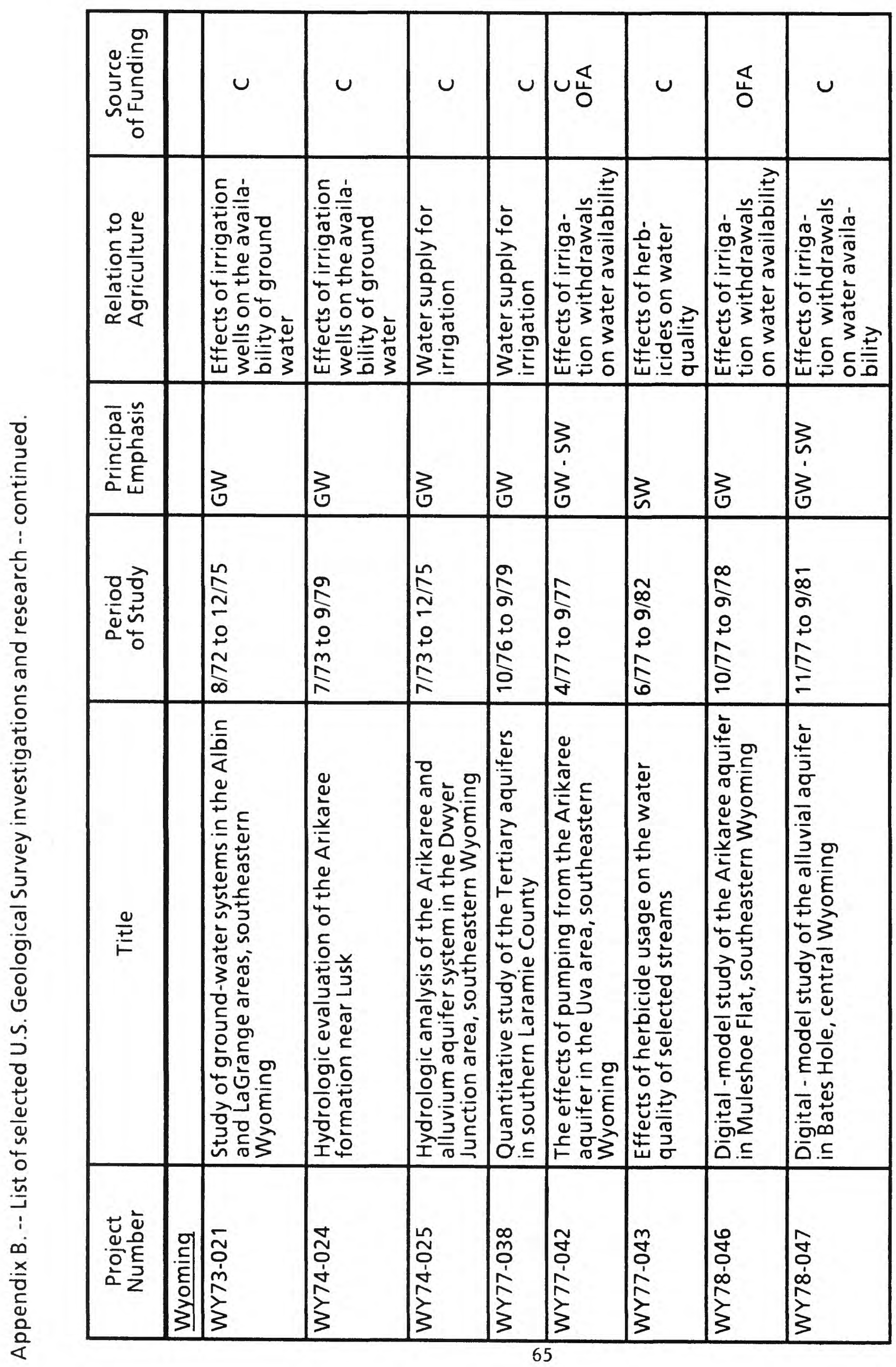




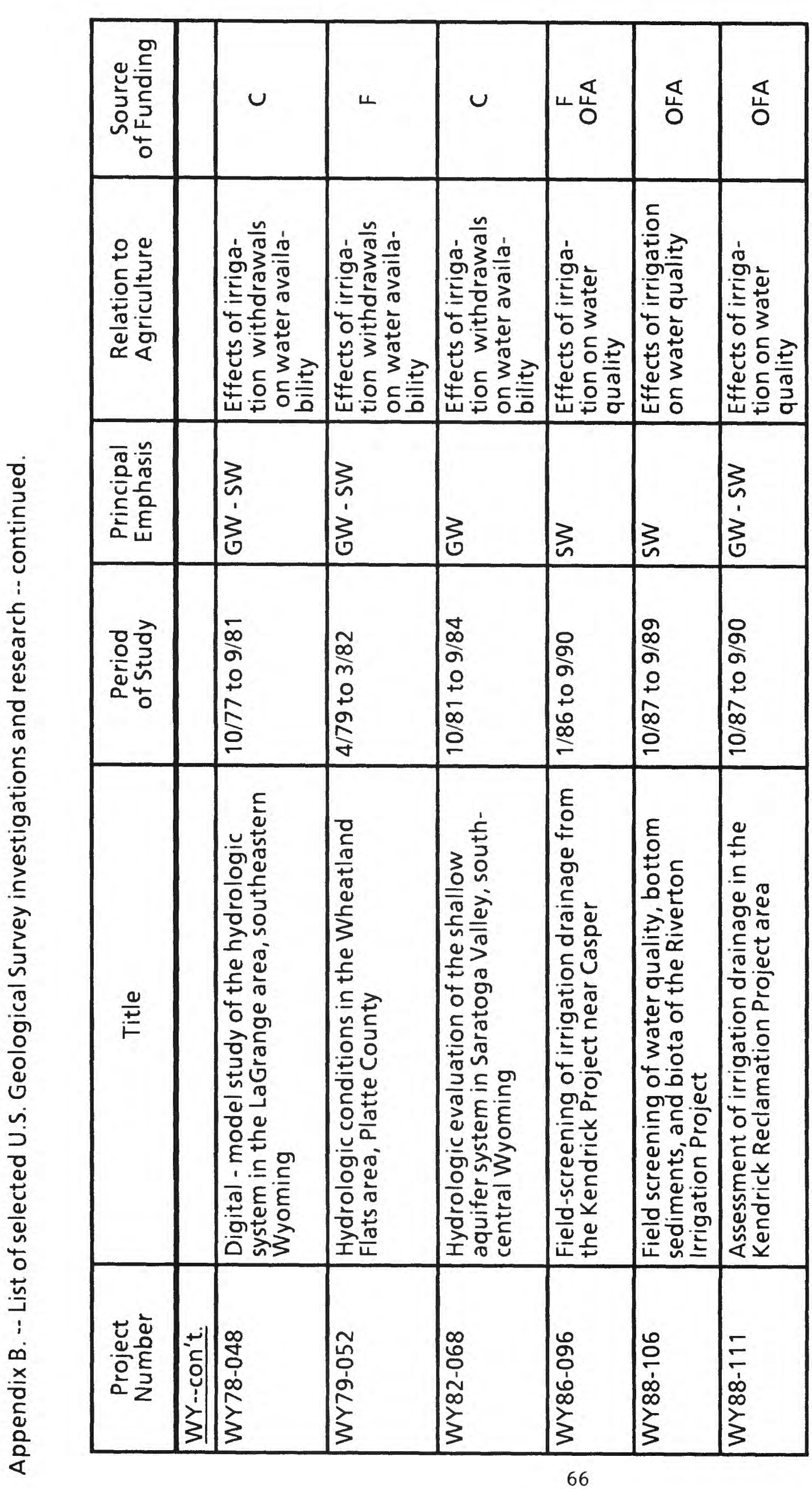



